\title{
Molecular Mechanisms of Lipid Metabolism Disorders in Infectious Exacerbations of Chronic Obstructive Pulmonary Disease
}

\author{
Stanislav Kotlyarov ${ }^{1, *(1)}$ and Anna Kotlyarova ${ }^{2}$ (D) \\ 1 Department of Nursing, Ryazan State Medical University, 390026 Ryazan, Russia \\ 2 Department of Pharmacology and Pharmacy, Ryazan State Medical University, 390026 Ryazan, Russia; \\ kaa.rz@yandex.ru \\ * Correspondence: SKMR1@yandex.ru
}

check for updates

Citation: Kotlyarov, S.; Kotlyarova, A. Molecular Mechanisms of Lipid Metabolism Disorders in Infectious Exacerbations of Chronic Obstructive Pulmonary Disease. Int. J. Mol. Sci. 2021, 22, 7634. https://doi.org/ 10.3390/ijms22147634

Academic Editors: Jéremy Jéremy Denizot, Elisabeth Billard and Hang Thi Thu Nguyen

Received: 16 June 2021

Accepted: 15 July 2021

Published: 17 July 2021

Publisher's Note: MDPI stays neutral with regard to jurisdictional claims in published maps and institutional affiliations.

Copyright: (c) 2021 by the authors. Licensee MDPI, Basel, Switzerland. This article is an open access article distributed under the terms and conditions of the Creative Commons Attribution (CC BY) license (https:// creativecommons.org/licenses/by/ $4.0 /)$.

\begin{abstract}
Exacerbations largely determine the character of the progression and prognosis of chronic obstructive pulmonary disease (COPD). Exacerbations are connected with changes in the microbiological landscape in the bronchi due to a violation of their immune homeostasis. Many metabolic and immune processes involved in COPD progression are associated with bacterial colonization of the bronchi. The objective of this review is the analysis of the molecular mechanisms of lipid metabolism and immune response disorders in the lungs in COPD exacerbations. The complex role of lipid metabolism disorders in the pathogenesis of some infections is only beginning to be understood, however, there are already fewer and fewer doubts even now about its significance both in the pathogenesis of infectious exacerbations of COPD and in general in the progression of the disease. It is shown that the lipid rafts of the plasma membranes of cells are involved in many processes related to the detection of pathogens, signal transduction, the penetration of pathogens into the cell. Smoking disrupts the normally proceeded processes of lipid metabolism in the lungs, which is a part of the COPD pathogenesis.
\end{abstract}

Keywords: COPD; exacerbations; immune response; inflammation; lipid metabolism; phagocytosis; lipid rafts

\section{Introduction}

Chronic obstructive pulmonary disease (COPD) is a chronic inflammatory disease, the prevalence and social significance of which is of increasing concern to clinicians and researchers [1-4]. It is shown that COPD is among the leading causes of morbidity and mortality worldwide $[5,6]$. As forecasts predict, the medical and economic burden of the disease will only grow.

Despite the available advances in COPD research, the keys to understanding all the pathophysiological mechanisms underlying both the disease itself and its comorbid interactions are still unknown. It is also not fully understood how one major etiological factor-cigarette smoking — can initiate the development of differences in clinical characteristics variants of COPD course.

Exacerbations are considered an important part of the clinical heterogeneity of COPD, they can modulate the nature of the course and mediate the relationship with comorbid diseases [7]. Exacerbations are events in the natural course of COPD, which are characterized by an increase in the severity of chronic respiratory symptoms (shortness of breath, cough, and sputum production) that go beyond their daily variability [8,9]. Exacerbations are associated with a deterioration in the quality of life and prognosis [10]. Taking into account the influence of exacerbations on the character of the course of the disease, some authors suggest that frequent exacerbations should be considered as a separate phenotype of COPD [11-13]. 
The mechanisms whose disorders are associated with exacerbations of COPD are of great clinical and research interest [14]. Exacerbations can be caused by many different factors, including viruses, bacteria, and aeropollutants $[9,15,16]$. It is shown that bacterial colonization of the bronchi makes a significant contribution to the progression of COPD [17].

The data accumulated in recent years leave no doubts that lipid metabolism disorders are widely involved in the pathogenesis of COPD [18-20]. These disorders occur at different levels and participate in both the development of inflammation and the formation of pulmonary and extrapulmonary clinical heterogeneity of the disease [21]. It is shown that lipid metabolism is connected with the development of COPD phenotypes, such as emphysema [22]. Interestingly, dyslipidemia causes multidirectional effects on innate immunity in the lungs and in the body in general, which is associated with the unique lipid biology of the lungs [23].

\section{Lipid Metabolism and Its Disorders in COPD}

Lipids play an important role in providing lung function. They perform not only a structural or energy function but also act as participants in many processes [24,25]. The lipid metabolism in the lungs is extremely complex, characterized by the participation of many types of lipids, and has specific features characteristic of different cell types. Some cells may even have their own characteristics of lipid metabolism associated with their differentiation and functional activity [26,27]. This complexly maintained lipid homeostasis of the lungs participates in providing an immune response and regulating inflammation.

The role of lipids in the immunometabolic reprogramming of macrophages is well known $[28,29]$. It is shown that the inflammatory activation of macrophages is largely related to the peculiarities of cellular metabolic processes and has a complex, not fully studied regulation $[28,30]$. Proinflammatory activated M1 macrophages are characterized by enhanced glycolysis and an increase in the synthesis of fatty acids, which are used as precursors for the synthesis of inflammatory mediators. In addition, they are characterized by a disturbed tricarboxylic acid (TCA) cycle and oxidative phosphorylation (OXPHOS). At the same time, anti-inflammatory M2 macrophages have intact TCA, OXPHOS, and enhanced fatty acid oxidation (FAO) [29,31-34].

The relative stability of the continuous processes of lipid metabolism in the cells of the respiratory tract is disrupted during smoking $[19,20]$. Circulating mononuclear cells in healthy smokers and patients with COPD demonstrate a reduced ability to utilize glucose. However, in patients with COPD, there is also a violation of the oxidation of fatty acids. In healthy smokers, the rate of fatty acid metabolism in mononuclear cells correlated positively with the parameters of lung function [32].

Tobacco smoke is a complex, not fully studied mixture of several thousand different chemicals, including many free radicals, which can have a significant effect on the lipids of the lungs [35]. Exposure to cigarette smoke causes lipid peroxidation in the bronchial epithelium and also leads to the redistribution of various lipid fractions [36].

Smoking leads to cytoplasmic accumulation of lipids [37] and also causes a decrease in the fluidity of the plasma membrane of alveolar macrophages, which is associated with a change in its lipid composition [38]. Exposure to cigarette smoke affects the metabolism of fatty acids in the cells of the respiratory tract, leading to a violation of the ratio of saturated and unsaturated fatty acids in the composition of phospholipids of the plasma membranes of cells [39].

The metabolism of fatty acids is disturbed both in a stable state and during exacerbations of COPD [40]. Moreover, it concerns both free fatty acids and fatty acids in the composition of phospholipids. With a stable course of COPD significantly lower levels of free alpha-linolenic acid, linoleic acid, and eicosapentaenoic acid are found in sputum compared to the control group [39,40]. It is shown that free polyunsaturated fatty acids (PUFA) have an antimicrobial effect, which is associated with a direct effect on the membranes of bacterial cells, as well as due to the formation of their bioactive metabolites that affect 
phagocytosis [41]. Interestingly, during COPD exacerbation a slight increase in the levels of PUFA (free arachidonic acid and docosapentaenoic acid) compared to stable COPD was being observed [39]. It should be noted that in contrast to $\omega-3$ PUFA, $\omega-6$ PUFA, such as arachidonic acid, increase inflammation in COPD [42,43].

The indicated changes in the lipid composition are a part of many processes connected with the fluidity of the plasma membrane, the organization of lipid rafts, the assembly, and functioning of receptor signaling pathways that provide cross-links of lipid metabolism, disturbed during smoking and COPD with microbial colonization of the bronchi and infectious exacerbations of the disease.

\subsection{The Importance of Lipid Rafts in the Pathogenesis of COPD}

A growing amount of evidence reinforces the understanding of the significance of plasma membrane lipid rafts in the interaction of pathogens with lung cells [44,45]. Lipid rafts are special structures of the plasma membrane of cells that are enriched with cholesterol and sphingolipids and act as dynamic platforms that recruit a number of signaling and transport proteins and provide many important cellular functions [46]. It should be noted that since the moment of its description [47], the concept of lipid rafts has been the subject of active discussions, including discussion of not only the structure and function of rafts but also of the very fact of their existence.

Cholesterol, the predominant component of lipid rafts, makes a significant contribution to their structural organization [48]. It is assumed that having a polycyclic sterane ring, cholesterol provides a more dense packing of lipids in rafts, which increases their viscosity compared to non-raft domains. Membrane proteins reside temporarily in lipid rafts and their function depends on localization in lipid rafts, including due to specific lipid-protein interactions $[49,50]$. Structural changes in lipid rafts and their disorganization caused by changes in the content of individual lipid components lead to changes in the function of the proteins associated with them. Saturated and polyunsaturated fatty acids have different effects on the structure and function of lipid microdomains [51,52].

Currently, two types of plasma membrane lipid domains are well characterized: flat lipid rafts enriched with glycosylphosphatidylinositol (GPI) and related to it proteins, and so-called caveols, which are invaginated into the cell microdomains, stabilized by structural proteins caveolins [53], among which the main framework protein is caveolin-1, which forms oligomeric structures and is present in many cell types, including epithelial cells of the respiratory tract [54]. It is assumed that caveols are more stable than flat lipid rafts. These lipid microdomains provide the implementation of many biological processes, including signal transduction, cellular metabolism, cell growth, and proliferation, apoptosis, and they also take part in the development of pulmonary inflammation [55-59].

It is assumed that the average size of lipid rafts varies from 10 to $200 \mathrm{~nm}$ [60], while the diameter of the caveol opening on the surface of the plasma membrane is $60-80 \mathrm{~nm}[61,62]$. It is believed that caveols can have different forms, including flat, tubular or vesicular [63]. Despite a certain similarity in lipid composition, there is no convincing evidence of the possibility of mutual transition between caveols and flat lipid rafts [64].

The significance of caveolin-1 is emphasized by the fact that knockout of the Cav1 gene leads to the loss of caveols by cells [65] and the development of lung lesions characterized by thickening of the alveolar septa due to endothelial cell hyperproliferation and fibrosis [65]. Due to its ability to regulate NO production via endothelial NO synthase (eNOS), caveolin1 participates in the activation of nuclear factor kappa-light-chain-enhancer of activated $\mathrm{B}$ cells (NF-kB) and the inflammatory response of the lungs to the lipopolysaccharides of the cell wall of gram-negative bacteria (LPS) [66].

It is assumed that cholesterol interacts directly with caveolin-1 thanks to the cholesterol recognition/interaction amino acid consensus domain (CRAC) [67]. Cholesterol depletion reduces the number of caveols, while excessive cholesterol saturation, on the contrary, leads to a decrease in the fluidity of plasma membranes and an increase in the number of caveols [68]. 
Cellular transport and export of lipids are subjects of close study, taking into account their significance for lung diseases [69]. This significance is well illustrated by the fact that the lungs are an organ with a high level of expression of the protein ATP binding cassette transporter $\mathrm{A} 1$ ( $\mathrm{ABCA} 1$ transporter). $\mathrm{ABCA} 1$ is considered a key participant in the process of reverse cholesterol transport and provides the formation of HDL by removing excess cholesterol from macrophages, in a process called reverse cholesterol transport [70]. Smoking reduces the expression and functional activity of $\mathrm{ABCA1}$, which leads to intracellular accumulation of cholesterol and inflammatory activation of macrophages [71,72].

Another fact that could demonstrate the important role of lipids in lung function is the data on the participation of ABCG1 in the inflammatory response. ABCG1, like ABCA1, is involved in lipid transport processes, including the formation of HDL. The transporter is highly expressed in alveolar macrophages and type 2 pneumocytes and carries out cholesterol export, reducing its intracellular accumulation. Experimental data showed that mice with a knockout of the Abcg1 gene have an enhanced inflammatory response to gram-negative bacteria in the lungs, characterized by the participation of neutrophils, as well as increased cytokine production, compared to wild-type individuals. Although the Abcg1 - / - mice showed an increase in bacterial clearance in the lungs and a decrease in extrapulmonary bacterial spread, this effect was not prognostically positive, since excessive inflammation caused the development of structural and functional changes in the lungs and led to a higher mortality rate among Abcg1 - / - mice [73].

The decrease in the expression of ABCA1 and ABCG1 in the lungs of COPD patients is well known from the results of in vitro and in vivo studies [72,74], which emphasizes the importance of lipid metabolism disorders in the pathogenesis of the disease.

The interest in $A B C$ transporters is enhanced by the data on their key role in ensuring the asymmetry of plasma membrane lipids [75]. It is shown that the level of expression and functional activity of $\mathrm{ABCA} 1$ determines the distribution of phospholipids between the plasma membrane sheets [76-79] since the transporter can fulfill their transfer both from the inner to the outer sheet, and participate in their horizontal movement. ABCA1-mediated changes in the distribution of membrane lipids determine the physicochemical properties of the plasma membrane and are important for the spatial organization of membrane proteins and, accordingly, their functional activity.

An increase in expression and functional activity of ABCA1 leads to a significant redistribution of cholesterol and sphingomyelin from rafts to the remaining part of the plasma membrane, while caveolin is also redistributed from caveols to the general region of the plasma membrane [80]. Thus, ABCA1 contributes to the destabilization of lipid microdomains [80-82]. This information can be confirmed by experimental data, in which mice with ABCA1 deficiency showed increased lipid rafts and inflammatory cell activation, accompanied by increased TNF-alpha production, against the background of reduced lipid export from macrophages [82].

These data give a possibility to assess the role of $A B C$ transporters and the violation of their function in smoking and COPD. Interestingly, LPS suppresses ABC-mediated reverse cholesterol transport in human macrophages [83], promoting the accumulation of cellular cholesterol and enhancing the inflammatory activation of macrophages.

Thus, lipid rafts ensure the assembly and functioning of many signaling pathways, including those that provide detection of extracellular pathogens, and the modulation of the lipid phase of the plasma membrane affects the organization and function of membrane proteins.

\subsection{Participation of Lipids in the Regulation of TLR Signaling Pathways}

It is shown that the immune surveillance and detection of a large number of pathogens in the lungs are carried out by representatives of the family of Toll-like receptor (TLR) macrophages. TLRs are expressed by many cell types, including epithelial cells, endothelial cells, monocytes, macrophages, dendritic cells, T- and B-lymphocytes. The most studied Toll-like receptor, TLR4, is localized both in the plasma membrane and in endosomes and 
recognizes LPS of gram-negative bacteria [84], which occupy a significant place in the structure of the causes of infectious exacerbations of COPD.

TLR4-mediated signaling is of great importance for COPD [85,86]. Interestingly, in addition to LPS, exogenous oxidants and components of tobacco smoke can activate TLR4 in the lungs [87-89].

Accumulating data are evidence of the important role of lipids in TLR4 function. It is shown that TLR4 is localized in the lipid rafts of the plasma membrane, the stability of which affects the function of the receptor [90]. Direct interaction of TLR4 with the cholesterol of lipid rafts is assumed. Thus, the regulation of TLR4 activity can be carried out through changes in the cholesterol content in the lipid rafts of the plasma membranes of macrophages [90].

Taking into account that the ABCA1 transporter is a key participant in cholesterol transport that affects the stability of lipid rafts, a decrease in its expression and functional activity during smoking leads to a decrease in the export of cholesterol from macrophages, which causes the initialization of inflammation by several mechanisms [91,92]. In its turn, TLR4 activation inhibits ABCA1 expression, which greatly reduces the outflow of cholesterol from macrophages [93,94].

Interesting data are that saturated fatty acids can also activate TLR4 $[84,95,96]$. Moreover, unlike saturated fatty acids, unsaturated ones do not have such an effect [96]. At the same time, several studies have shown the anti-inflammatory effect of $\omega-3$ PUFA, which is realized through the inhibition of TLR4 signal transduction [97].

The biological function of this is not clear, but thanks to these and other data it is clear that TLR4 activation is modulated by endogenous lipids. Chemical modification of LPS with the replacement of saturated fatty acids with unsaturated ones eliminates the inflammatory activation of TLR [98].

Ceramide, whose elevated levels are detected in the lungs of smokers and COPD patients [99-102], also has the ability to activate TLR4 signal transfer in epithelial cells [103,104], due to its structural similarity to bacterial LPS $[103,105]$. Assembly and activation of the TLR4 receptor after binding of LPS to CD14 require the production of ceramide by acidic sphingomyelinase [106]. It is shown that LPS and palmitic acid contribute to the increase of ceramide production by increasing the hydrolysis of sphingomyelin by stimulating the activity of acid sphingomyelinase [107-109].

Ceramide is a participant in structural apoptosis of the alveolar epithelium and endothelial cells, as well as violation of efferocytosis by alveolar macrophages in the emphysematous lung $[101,110]$. In this regard, it is believed that these representatives of sphingolipids are involved in the development of emphysema [101], a frequent phenotype of COPD.

The presented studies confirm strongly the opinion about the important role of the lipid architecture of plasma membranes in the signaling function of TLR4 and its possible violations in the modification of this architecture.

Taking into account these and other facts, it is interesting to know how disorders of lipid metabolism in COPD patients are associated with infectious exacerbations and disease progression.

\section{Bacterial Infection in the Pathogenesis of Stable Course and Exacerbations of COPD}

The lungs are constantly in contact with a large number of microorganisms and aeropollutants when breathing. Taking into account the large surface area of the lungs and the volumes of air that a person inhales daily, the airways require a reliable functioning of the immune system. Interestingly, the bronchial tree of healthy people, which was previously considered sterile, actually contains a diverse microbial community [111-113]. Representatives of the genera Pseudomonas, Streptococcus, Prevotella, Fusobacterium, Haemophilus, Veillonella, and Porphyromonas are most often found in healthy airways [113-119]. It is assumed that in healthy people the lung microbiota is not a permanent community, but is represented by temporarily present microorganisms, the source of which is the upper 
respiratory tract [120-123]. It is known that even healthy people are characterized by microaspiration of the contents of the upper respiratory tract [124], whereas in COPD it and the damaging effect of smoking suppress additionally mucociliary clearance of the bronchi [125-128], which contributes to an increase in the population of the microorganisms into the lungs $[120,129-131]$. It should be noted that despite the fact that smoking disrupts the human immune response, there are no data on the direct effect of smoking on the microbiome of the lower respiratory tract $[127,132,133]$. Changes in the air flow in the bronchi, characteristic of COPD should also be related to the factors affecting the dynamics and character of the migration of microorganisms into the respiratory tract [124].

It is believed that representatives of the normal respiratory microbiome are metabolically active and participate in providing immune homeostasis in the respiratory tract $[123,127]$. By regulating the function of alveolar macrophages, the microbiota can enhance resistance to a variety of bacterial and viral pathogens [134]. Several studies have demonstrated changes in the structure of the microbiota in the lower respiratory tract during the transition of COPD from a stable state to an exacerbation, which may reflect the dynamism of the ongoing processes associated with the persistence of microflora [113,135-142].

Bacterial infections are an important cause of COPD exacerbations [113,143-148]. During exacerbation Haemophilus influenzae, Moraxella catarrhalis, Pseudomonas aeruginosa, Klebsiella pneumoniae, Streptococcus pneumoniae, Staphylococcus aureus are most often detected $[116,117,119,135,149-155]$. In a severe course of exacerbations in patients with severe stages of the disease, the structure of the microflora may change with the predominance of Pseudomonas spp. [116,141,143,153,156,157].

Bacteria can use different strategies for using lung lipids when colonizing the lungs $[158,159]$. Currently, extensive data on the involvement of host lipids in the metabolism of bacterial pathogens have been obtained. An important source of free phospholipids and sphingolipids in the human host organism for bacteria is the lung surfactant [160]. For example, P. aeruginosa uses phosphatidylcholine for growth [161-163].

In addition, with various tools associated with the assimilation of host lipids, their structural or stereochemical modification, bacteria have developed many tactics for using lipids to increase their virulence [159].

\section{Cross-Links of Lipid Metabolism and Bacterial Infection in the Lungs}

Recent studies demonstrate convincingly the ability of some viruses and bacteria to use the endocytic properties of lipid microdomains to enter cells [164-168]. It is also shown that cigarette smoke alters the function of several important endocytic pathways in the epithelial cells of the respiratory tract, increasing caveolin-mediated endocytosis, which may contribute to lung infection in smokers [169].

P. aeruginosa, an important participant in severe exacerbations of COPD, has the ability to enter epithelial cells through caveolin-rich lipid microdomains of the plasma membrane [57,170-172].

Several studies have shown that acidic sphingomyelinase and ceramide play an important role in the infection of cells with P. aeruginosa [173]. It was found that $P$. aeruginosa can initiate the activation of acidic sphingomyelinase, which hydrolyzes sphingomyelin [174,175] to form ceramide.

Due to their biophysical properties ceramide molecules self-associate and reorganize sphingolipid-rich rafts through hydrophobic interactions, creating larger microdomains with unique biophysical properties that are necessary for the transmission of diverse signals and clustering of several molecules, such as NADPH-oxidase, CD95, and cystic fibrosis transmembrane conduction regulator (CFTR) [171,176-178]. Interestingly, these ceramiderich platforms are used by $P$. aeruginosa for internalization into the cell [171,177]. Genetic deficiency of acidic sphingomyelinase increases the susceptibility of mice to $P$. aeruginosainduced pulmonary inflammation, generalization of infection, and death [171].

Activation of mitochondrial acidic sphingomyelinase is another tool for regulating $P$. aeruginosa inflammation, since the formation of mitochondrial ceramide increases 
the permeability and release of cytochrome $C$ from mitochondria and causes neutrophil death [179-181]. By regulating the activity of acidic sphingomyelinase, $P$. aeruginosa not only participates in the reorganization of plasma membranes with the formation of platforms enriched with ceramides but also can influence other immune processes, taking into account the fact that ceramide and sphingosine take part in the protection of the lungs from bacterial pathogens [21].

The structural component of caveols, the protein caveolin-1, plays an important role in the immune defense of the lungs. It is shown that it is involved in the regulation of various signaling pathways and inflammatory responses associated with infection with K. pneumoniae [182] and P. aeruginosa [183,184]. Mice with a knockout of the Cav1 gene have an increased sensitivity to $P$. aeruginosa, which correlates with a reduced ability of neutrophils with caveolin-1 deficiency to phagocytize P. aeruginosa [185]. The significance of caveols is well demonstrated by a study that showed that mice with a knockout of the Cav1 gene infected with $P$. aeruginosa had increased mortality due to severe lung damage and generalization of infection compared to wild-type mice. In addition, these mice showed increased production of inflammatory cytokines (IL-6, TNF- $\alpha$, and IL-1 $\beta$ ) associated with the activation of the Cav-1/STAT3/NF-kB axis, as well as the reduced phagocytic capacity of macrophages and a marked increase in lipid peroxidation in the lungs [183].

It is known that $\mathrm{ABCA} 1$ co-localizes and interacts with caveolin-1, which initiates the oligomerization of caveolin-1, which is necessary for its intracellular transport from the Golgi compartment to the plasma membrane [186]. P. aeruginosa increases the expression of ABCA1, thereby being able to influence the transport of lipids [187]. This ability to influence a key lipid transport protein appears to be extremely important for the pathogenesis of COPD.

The Gram-negative bacterium K. pneumoniae can also enter lung epithelial cells through lipid rafts [182,188]. Cholesterol plays an important role in this interaction, and the reorganization of lipid rafts participates in protecting the host from K. pneumoniae infection [182,189]. The destruction of lipid rafts by methyl- $\beta$-cyclodextrin inhibits the internalization of K. pneumoniae into lung cells [182]. It should be noted that the biological function of internalization of $K$. pneumoniae by respiratory epithelial cells is a subject of discussion since on the one hand, it can be a useful mechanism for the pathogen, as it promotes bacterial replication and evasion of occupational phagocytes, while on the other hand, the respiratory epithelium is a participant in the antimicrobial defense of the lungs [190-195].

Experimental data show that cholesterol affects the expression of K. pneumoniae virulence factors, the key of which is the capsule polysaccharide, which provides resistance to phagocytosis $[196,197]$. It was found that cholesterol interferes with the formation of capsule polysaccharides, which increases macrophage-mediated phagocytosis but does not affect the adhesion of the bacterium to epithelial cells [188]. Depletion of cholesterol from cell membranes, on the contrary, stimulates the production of capsule polysaccharide, reducing phagocytosis of K. pneumoniae by macrophages. It has been shown that cholesterol reduces the antiphagocytic properties of the K. pneumoniae capsule, promoting the absorption of bacterium by macrophages [188].

In addition to the capsule polysaccharide, cholesterol is also able to suppress the expression of genes encoding LPS and K. pneumoniae outer membrane proteins. [188].

Fatty acids participate in the regulation of gene expression in some pathogens, and also affect their motility and survival. At the same time, polyunsaturated fatty acids have an inhibitory effect on P. aeruginosa. P. aeruginosa reacts to exogenous polyunsaturated fatty acids by changing the composition of phospholipids, membrane permeability, and phenotypes associated with virulence [198]. Linoleic and arachidonic acids although not synthesized by $P$. aeruginosa, but are included in the membrane phospholipids of the bacterium. Interestingly, arachidonic acid increases the resistance of the pathogen to certain antimicrobial drugs. It is assumed that the inclusion of arachidonic acid in the structure of the bacterial membrane may change its stereochemistry, with the help of enzymes such as cis/trans isomerase, which affects the permeability of the membrane and protects 
the bacterium from antimicrobial drugs [198-200]. Thus, the uptake and assimilation of arachidonic acid from the foci of infection may be beneficial for the colonization of $P$. aeruginosa [198] but may reduce the inflammatory response to infection due to impaired synthesis of eicosanoids [201-203].

K. pneumoniae is also able to assimilate fatty acids from the environment into its membrane phospholipids, which can affect its growth, virulence, and survival factors [204]. The length of the carbon chain and the degree of unsaturated fatty acid correlate with a decrease in bacterial growth [201]. At the same time, the inclusion of exogenous PUFAs leads to the destabilization of the bacterial membranes and increases their permeability for certain antimicrobial drugs. Interestingly, arachidonic acid promotes the colonization of K. pneumoniae, enhancing the formation of biofilms [201].

The lipid microdomains of plasma membranes are involved in the pathogenesis of other Gram-negative bacteria, such as M. catarrhalis [205]. Lipid rafts can be used not only for the penetration of bacterium into the cell but also for remote exposure to it through outer membrane-derived vesicles (OMV) in the absence of direct contact of bacteria with the host [205-207]. It is determined that the outer membrane-derived vesicles (OMV) secreted by $P$. aeruginosa, can deliver multiple virulence factors directly to the cytoplasm of epithelial cells of the respiratory tract through the fusion of OMV with the lipid rafts of the plasma membrane [206].

Thus, some bacteria can not only use the properties of plasma membranes for internalization into cells but also modulate their lipid structure and associated signaling pathways [181,208].

Modification of the fatty acid composition of membranes by bacteria is an important tool that affects the fluidity and permeability of bacterial membranes and, accordingly, the resistance to antimicrobial drugs [209-211].

\section{Participation of Lipids in Phagocytosis Disorders in COPD}

Phagocytosis is the most important mechanism that ensures the purification of tissues from foreign particles, microorganisms, and dead cells and is carried out by both professional and non-professional phagocytes [212,213]. The process of absorbing dead cells is called efferocytosis [214-216]. Macrophages are professional phagocytes and by their origin form two separate subpopulations in the lungs. Their number in the lungs in patients with COPD increases, which may be associated with increased recruitment of blood monocytes [217-220]. At the same time, both alveolar macrophages and macrophages differentiated from blood monocytes are characterized by defective efferocytosis and phagocytosis regarding a number of bacteria [221,222]. The phagocytic abilities of alveolar macrophages and macrophages derived from blood monocytes in COPD patients may differ, as was shown for $H$. influenzae, which provides an immunological basis for colonization of the respiratory tract by the bacterium in COPD $[223,224]$ and may be one of the causes of exacerbation development [225]. In addition, the phagocytosis defect in COPD is mainly characteristic of bacterial pathogens, but not of inert microspheres [222].

Defective phagocytosis of bacteria is one of the factors leading to colonization of the lower respiratory tract and the development of infectious exacerbations of the disease [221]. Violation of phagocytosis by macrophages is associated with the frequency of exacerbations [225] and the severity of COPD, determined by indicators of pulmonary function $[222,226]$. Tobacco smoke is known to reduce the ability of alveolar macrophages to phagocytosis and efferocytosis $[227,228]$. Cells that died due to apoptosis and were not subjected to timely efferocytosis may be the cause of chronic inflammation [229]. Lipids oxidized under the influence of cigarette smoke make a significant contribution to local immune responses. It has been shown that exposure to cigarette smoke causes the production of antibodies against oxidized lipids in the lungs of mice, which may contribute to limiting the response to damaged lipids [230]. Interestingly, the phagocytic function of macrophages was dose-dependent suppressed by the presence of oxidized epithelial lipids [36]. 
Exposure to cigarette smoke leads to the accumulation of lipids in lung macrophages, with the formation of a foam cell phenotype [231]. It should be noted that the accumulation of cholesterol in macrophages may be facilitated by a decrease in the expression and functional activity of the ABCA1 transporter during smoking. The function of ABCA1 in phagocytosis is to remove excess cholesterol that is formed during uptake, for example, of apoptotic cells. At the same time, cholesterol-loaded macrophages are less effective phagocytes, which corresponds to data on a decrease in the phagocytic activity of ABCA1 deficient macrophages. In addition, ABCA1 participates in the "find-me" and "eat-me" signals, which are necessary for phagocytosis and efferocytosis [232].

Thus, phagocytosis is closely related to lipid metabolism. Active phagocytosis leads to an increase in the rate of lipid metabolism, which may reflect the general metabolic stimulation accompanying this process [233]. The increased synthesis of phospholipids during phagocytosis [234] is associated with the need for their use for the formation of membranes of phagocytic vesicles [235].

It is shown that the phagocytic activity of macrophages is determined by the composition of the plasma membranes of cells. At the same time, the ratio of saturated and unsaturated fatty acids in phospholipids is important [236]. Experiments with the cultivation of macrophages in the presence of various fatty acids have shown that they are well incorporated into the composition of plasma membranes, affecting phagocytic activity, while its greatest increase is observed in the presence of cis unsaturated fatty acids [237].

Some bacteria have developed certain strategies that allow them to avoid death during phagocytosis [238]. There is strong evidence that K. pneumoniae survives phagocytosis by macrophages by regulating phagosome maturation. K. pneumoniae controls the maturation of phagosomes by regulating the PI3K-Akt-Rab14 axis, so that the bacterium does not die in macrophages, but is located in a special intracellular compartment that does not merge with lysosomes [189].

In addition, K. pneumoniae can disrupt efferocytosis, so that neutrophils infected with the bacterium are excreted through efferocytosis less efficiently than uninfected neutrophils [239]. For this purpose, K. pneumoniae can use several mechanisms, including reducing exposure to phosphatidylserine (PtdSer) by increasing flippase activity $[239,240]$. The localization of PtdSer on the outer sheet of the plasma membrane is known to be the «eat-me signal» for macrophage receptors that provide uptake of apoptotic cells [241]. In the plasma membranes of living cells flippases are responsible for the transport of PtdSer from the outer leaf to the inner leaf, whereas, in apoptosis, PtdSer moves in the opposite direction [242]. K. pneumoniae contributes to the shift of the cell death pathway from apoptosis to necroptosis of infected neutrophils $[239,243]$. Thus, disruption of apoptosis due to PtdSer translocation modulation and activation of necroptosis are independent mechanisms of disruption of neutrophil efferocytosis in K. pneumoniae. This allows the bacteria to enter the interstitium, avoiding uptake by macrophages $[239,240]$.

Thus, in COPD there is a violation of various phagocytosis mechanisms that can use bacterial pathogens for colonization.

\section{Participation of Lipids in the Resolution of Inflammation in COPD}

The information accumulated in recent years allows us to re-evaluate the variety of functions of lipids in various phases of inflammation. More and more evidence suggests that lipids are involved not only in the initiation of inflammation, such as prostaglandins and leukotrienes formed from arachidonic acid, but are also mediators of the highly organized phase of inflammation resolution [244-246]. Recently identified new families of mediators, called "specialized pro-resolving mediators" (SPM) play a key role in the active resolution of inflammation [247-250]. This class of endogenously produced bioactive lipids includes lipoxins, resolvins, protectins, and maresins, which are formed by oxygenation of $\omega-3$ and $\omega-6$ PUFA [251,252]. Moreover, lipoxins are synthesized by a series of enzymatic reactions from arachidonic acid [253,254], resolvins of the E series from eicosapentaenoic acid, and resolvins of the D-series and protecins, as well as maresins, are 
formed from docosahexaenoic acid [255-257]. Thus, PUFAs, if necessary released from membrane phospholipids, are an important source of not only pro-inflammatory, but also anti-inflammatory mediators [256-259].

The function of SPM is being studied actively, but the data available to date allow us to emphasize their significant role in inflammation, which is provided by the regulation of many lower signaling pathways [244,247,259-261]. SPM affect the decrease in the secretion of pro-inflammatory cytokines, and on the contrary, they contribute to an increase in the number of anti-inflammatory cytokines, through switching macrophages to the M2 phenotype, and also increase phagocytosis, which is important, taking into account that tobacco smoke stimulates macrophages pro-inflammatory [259,261-263].

Taking into account the importance of SPM in the resolution of inflammation, and the violation of this process in COPD, the role of lipid mediators is of great clinical interest [262,264-268]. The participation of resolvin RvD1 in tissue regeneration in emphysema caused by smoking has been shown [269]. It has also been determined that resolvins inhibit the production of pro-inflammatory cytokines TNF- $\alpha$ and IL-6 by alveolar macrophages in COPD, weakening the inflammatory effects caused by cigarette smoke [270,271]. SPM also improves bacterial clearance by activating phagocytosis, such as RvD1, which enhances phagocytosis of $P$. aeruginosa by neutrophils and macrophages [271,272].

Lipid mediators demonstrate dysregulation of concentrations in various biological substrates of COPD patients, including exhaled air condensate, bronchoalveolar lavage fluid, and blood serum. It was found that the levels of anti-inflammatory lipoxin LXA4 decrease in sputum in COPD patients during exacerbation, while there is an increased ratio of pro-inflammatory leukotriene B (4) (LtB (4)) to LXA4 (LtB (4)/LXA (4)) [273].

Taking into account the role of SPM in providing bacterial clearance in acute infection, it is interesting to consider the relationship of SPM with chronic persistent infection, which is characteristic of COPD [272]. In this regard, it should be noted that there are currently known examples of the use of local SPM production by some pathogens as a strategy for evading host immunity and survival $[261,262,274]$. It is shown that $P$. aeruginosa participates in the biosynthesis of SPM by activating cytosolic phospholipase A2, thereby increasing the available pool of arachidonic acid and then metabolizing it with the help of functional 15-lipoxygenase (15-LOX) [274-277].

Thus, taking into account the biological role of lipid mediators and experimental data on the effectiveness of SPM in resolving inflammation, overcoming immunosuppressive effects caused by tobacco smoke [267], this group of lipid mediators is of great interest from the point of view of finding new effective therapeutic strategies and developing drugs for the treatment of COPD $[270,271]$.

\section{Conclusions}

The existing extensive evidence supports the significant role of lipid metabolism disorders in the progression of COPD (Figure 1, Table 1). Normal lipid metabolism is important for lung function, and its disturbances during smoking may participate in the pathogenesis of COPD [278]. The mechanisms of such disorders are multifaceted, associated with the processes of lipid peroxidation, defects in the synthesis and transport of lipids [279].

According to modern concepts, the bilayer of the plasma membrane is not homogeneous in its lipid composition but is represented by a mosaic of tightly packed lipid microdomains. Lipid microdomains perform many physiological functions, including the assembly and functioning of signaling pathways, such as TLR4, which provides LPS detection of Gram-negative bacteria.

Maintaining the membrane asymmetry of lipids is a complex, not fully studied mechanism in which many pathways of cellular lipid metabolism intersect, including their synthesis, absorption, export, and storage. The transport of lipids, including cholesterol, which is considered to be an important structural component of lipid microdomains, has complex regulation and can be disrupted during smoking. The substrate of such disorders 
may be a decrease in the expression and functional activity of the ABCA1 transporter. Modified by changes in the transport activity of ABCA1 the lipid environment in which TLR4 is embedded may underlie functional disorders caused by smoking.

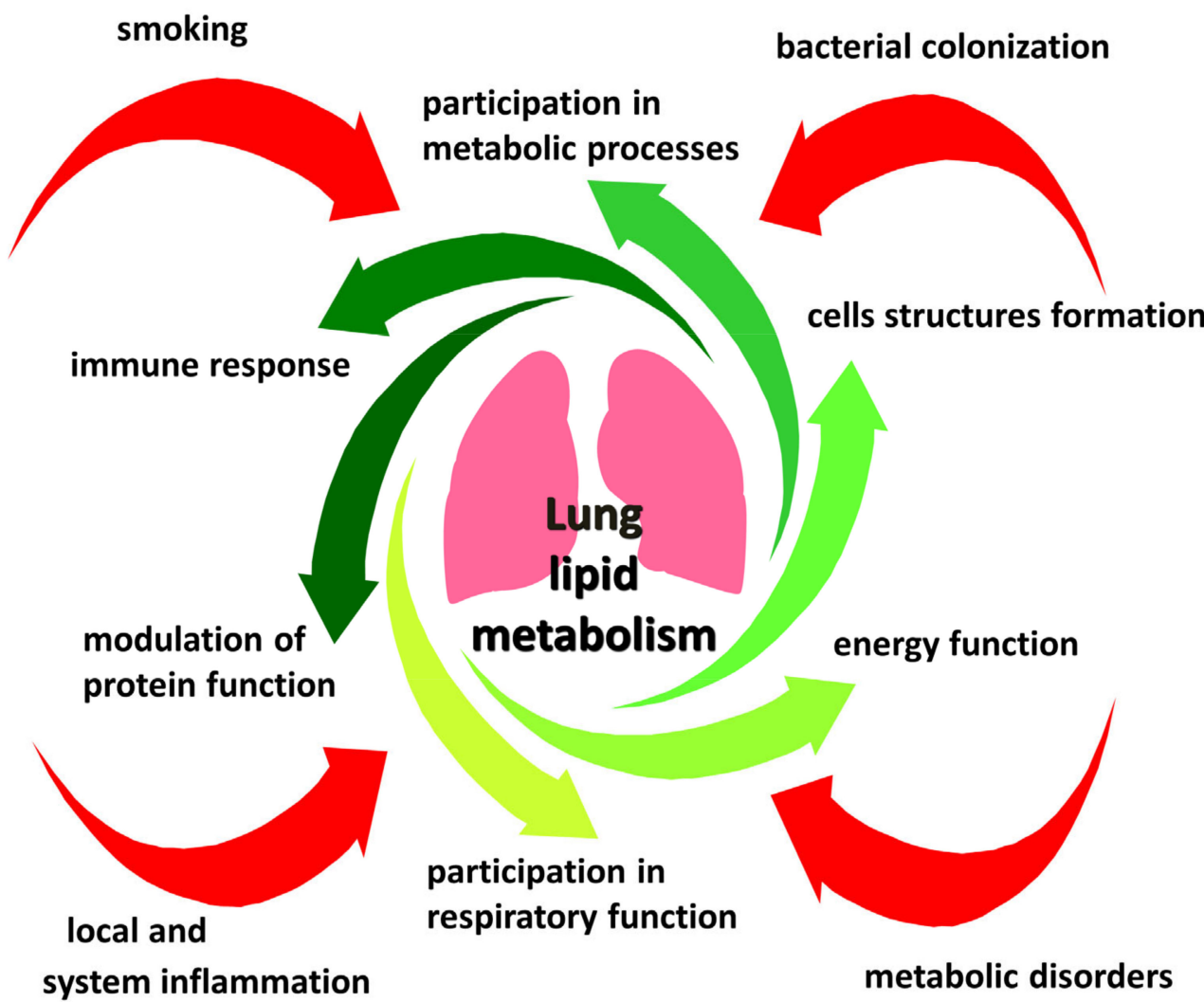

Figure 1. The role of pulmonary lipid metabolism.

Table 1. Lipids disorders in COPD.

\begin{tabular}{|c|c|c|c|}
\hline Lipids & $\begin{array}{c}\text { Disorders That Occur } \\
\text { during Smoking and COPD }\end{array}$ & $\begin{array}{l}\text { Processes Affected by Lipid } \\
\text { Metabolism Disorders }\end{array}$ & References \\
\hline Fatty acids & $\begin{array}{l}\text { Disorders in the ratio of } \\
\text { saturated and unsaturated } \\
\text { fatty acids in the composition } \\
\text { of membrane phospholipids; } \\
\text { change in the amount of free } \\
\text { fatty acids; } \\
\text { fatty acid oxidation disorders }\end{array}$ & $\begin{array}{l}\text { activation and resolution of } \\
\text { inflammation (lipid mediators of } \\
\text { inflammation); } \\
\text { activation of TLR4 signaling; } \\
\text { immuno-metabolism of } \\
\text { macrophages (fatty acid } \\
\text { oxidation) }\end{array}$ & {$[20,28-30,32-35,38-43,52,95,96,108,234-236]$} \\
\hline Phospholipids & $\begin{array}{l}\text { Disorders in the ratio of } \\
\text { saturated and unsaturated } \\
\text { fatty acids in the composition } \\
\text { of membrane phospholipids }\end{array}$ & $\begin{array}{l}\text { the fluidity and permeability of } \\
\text { plasma membranes; } \\
\text { participation in ensuring the } \\
\text { structure and function of the } \\
\text { plasma membrane; } \\
\text { organization of lipid rafts; } \\
\text { regulation of the membrane } \\
\text { protein function, including those } \\
\text { associated with inflammation; } \\
\text { participation in phagocytosis }\end{array}$ & {$[19,24,38-40,51,52,234-237]$} \\
\hline
\end{tabular}


Table 1. Cont.

\begin{tabular}{|c|c|c|c|}
\hline Lipids & $\begin{array}{c}\text { Disorders That Occur } \\
\text { during Smoking and COPD }\end{array}$ & $\begin{array}{l}\text { Processes Affected by Lipid } \\
\text { Metabolism Disorders }\end{array}$ & References \\
\hline Sphingolipids & $\begin{array}{l}\text { Smokers and patients with } \\
\text { COPD have elevated levels } \\
\text { of ceramides in the lungs }\end{array}$ & $\begin{array}{l}\text { increased structural apoptosis; } \\
\text { activation of TLR4 signaling; } \\
\text { organization of lipid rafts, } \\
\text { reorganization of lipid rafts } \\
\text { enriched with ceramide }\end{array}$ & {$[19-21,24,35,99-107,109,110,176-178]$} \\
\hline Cholesterol & $\begin{array}{l}\text { Disorders of reverse } \\
\text { transport of cholesterol from } \\
\text { macrophages during } \\
\text { smoking and COPD }\end{array}$ & $\begin{array}{l}\text { participation in ensuring the } \\
\text { structure and function of the } \\
\text { plasma membrane; } \\
\text { organization of lipid rafts; } \\
\text { regulation of the function of } \\
\text { membrane proteins, including } \\
\text { those associated with } \\
\text { inflammation; } \\
\text { phagocytosis disorders }\end{array}$ & {$[19,48-50,67,68,82,90-92,231]$} \\
\hline
\end{tabular}

The conducted analysis showed that lipid rafts are involved in the pathogenesis of COPD, as they provide many important cellular functions and participate in the immune response. Disruption of the structure and function of lipid rafts in smoking and COPD is part of the pathogenesis of COPD. These disorders participate in bacterial colonization of the bronchi, lead to an increase in inflammation.

A growing body of evidence leaves no doubt that some bacteria and viruses use the lipid microdomains of the plasma membrane for interaction, binding, and possible penetration into cells $[164,165]$. Some pathogens can affect the lipid metabolism in the host cells by realizing their virulence, as well as using the host lipids as a food source or assimilating them into their metabolic or structural processes [280]. For colonization of the lungs in COPD bacteria use many other strategies, including modification of the lipid composition of the membrane, which affects its permeability for antibacterial drugs, the formation of biofilms, and the exclusion of certain lipids from the host metabolic and immune processes [281].

It should be noted that not only the natural course of COPD determines all the features of the lipid metabolism of the lungs. These processes can be modulated under the influence of certain medications used to treat both the underlying disease and comorbid pathology. Information about the role of inhaled corticosteroids (ICSs), which can be used in COPD, is interesting [282,283]. It is believed that they are most effective in eosinophilic exacerbations of the disease, especially when combined with bronchial asthma (asthmaCOPD overlap), but their use is ambiguous in infectious exacerbations of COPD when ICSs can increase the risk of pneumonia [283-285]. This may be due to a complex effect on various phases of inflammation [286]. Glucocorticoids affect the lipid metabolism of the lungs, due to their ability to inhibit the activity of phospholipase A2 [287], the enzyme responsible for the formation of arachidonic acid [288] and, accordingly, many inflammatory mediators $[289,290]$, including the synthesis of prostaglandins, leukotrienes, and lipoxins [291]. Modulation of the synthesis of lipid mediators can change the immune response and the character of the course of infectious exacerbations in COPD.

Taking into account the significant role of lipid metabolism in lung function and disorders of this metabolism in COPD, it is logical to assume a positive role of taking statins, which have an anti-inflammatory pleiotropic effect [292-295]. However, studies conducted on this topic do not give a clear answer on the effectiveness of taking statins. They were unable to demonstrate a clear improvement in lung function and mortality from COPD [293,294,296,297], although they confirmed a decrease in the level of inflammation and a decrease in the negative impact of cardiovascular comorbidity $[294,297,298]$. The effect of statins on the frequency and severity of exacerbations is also a subject of discussion, 
although in some studies the use of this group of drugs has been associated with a reduced risk of hospitalizations associated with exacerbations [294,298-302].

The anti-inflammatory effect of statins includes various mechanisms, including the effect on the function of macrophages, direct antibacterial activity [303-308]. The effect of statins on the biophysical properties of plasma membranes and the function of membrane proteins is also shown, which is undoubtedly the subject of further research $[309,310]$.

Thus, currently available data suggest that the leading role of lipid metabolism in the lungs is not only as a structural or energy substrate but also as a full-fledged participant in the immune defense of the lungs. The multifaceted role of lipids in the function of the immune defense of the lungs is only beginning to be understood. It can be assumed that lung lipids are at the intersection of many pathways of the innate immune response. Thus, the lipid metabolism in the lungs is a complex system, the keys to understanding all the mechanisms of which are still not available to clinicians and researchers.

Funding: This research received no external funding.

Institutional Review Board Statement: Not applicable.

Informed Consent Statement: Not applicable.

Data Availability Statement: Not applicable.

Conflicts of Interest: The authors declare no conflict of interest.

\section{References}

1. Soriano, J.B.; Kendrick, P.J.; Paulson, K.R.; Gupta, V.; Abrams, E.M.; Adedoyin, R.A.; Adhikari, T.B.; Advani, S.M.; Agrawal, A.; Ahmadian, E.; et al. Prevalence and attributable health burden of chronic respiratory diseases, 1990-2017: A systematic analysis for the Global Burden of Disease Study 2017. Lancet Respir. Med. 2020, 8, 585-596. [CrossRef]

2. Quaderi, S.A.; Hurst, J.R. The unmet global burden of COPD. Glob. Health Epidemiol. Genom. 2018, 3, e4. [CrossRef] [PubMed]

3. Blanco, I.; Diego, I.; Bueno, P.; Casas-Maldonado, F.; Miravitlles, M. Geographic distribution of COPD prevalence in the world displayed by Geographic Information System maps. Eur. Respir. J. 2019, 54, 1900610. [CrossRef] [PubMed]

4. Lokke, A.; Lange, P.; Lykkegaard, J.; Ibsen, R.; Andersson, M.; de Fine Licht, S.; Hilberg, O. Economic Burden of COPD by Disease Severity-A Nationwide Cohort Study in Denmark. Int. J. Chronic Obs. Pulm. Dis. 2021, 16, 603-613. [CrossRef] [PubMed]

5. Hashemi, S.Y.; Momenabadi, V.; Faramarzi, A.; Kiani, A. Trends in burden of chronic obstructive pulmonary disease in Iran, 1995-2015: Findings from the global burden of disease study. Arch. Public Health 2020, 78, 45. [CrossRef] [PubMed]

6. Çolak, Y.; Afzal, S.; Nordestgaard, B.G.; Vestbo, J.; Lange, P. Prevalence, Characteristics, and Prognosis of Early Chronic Obstructive Pulmonary Disease. The Copenhagen General Population Study. Am. J. Respir. Crit. Care Med. 2020, 201, 671-680. [CrossRef] [PubMed]

7. Viniol, C.; Vogelmeier, C.F. Exacerbations of COPD. Eur. Respir. Rev. 2018, 27. [CrossRef] [PubMed]

8. Celli, B.R.; MacNee, W. Standards for the diagnosis and treatment of patients with COPD: A summary of the ATS/ERS position paper. Eur. Respir. J. 2004, 23, 932-946. [CrossRef]

9. Papi, A.; Luppi, F.; Franco, F.; Fabbri, L.M. Pathophysiology of exacerbations of chronic obstructive pulmonary disease. Proc. Am. Thorac. Soc. 2006, 3, 245-251. [CrossRef]

10. Çolak, Y.; Afzal, S.; Marott, J.L.; Nordestgaard, B.G.; Vestbo, J.; Ingebrigtsen, T.S.; Lange, P. Prognosis of COPD depends on severity of exacerbation history: A population-based analysis. Respir. Med. 2019, 155, 141-147. [CrossRef]

11. Brill, S.; Jones, T.; Brown, J.; Hurst, J.; Vancheeswaran, R. COPD exacerbation phenotypes in a five year hospitalisation cohort. Eur. Respir. J. 2018, 52, PA3863. [CrossRef]

12. Vestbo, J. COPD: Definition and Phenotypes. Clin. Chest Med. 2014, 35, 1-6. [CrossRef]

13. Mirza, S.; Benzo, R. Chronic Obstructive Pulmonary Disease Phenotypes: Implications for Care. Mayo Clin. Proc. 2017, 92, 1104-1112. [CrossRef] [PubMed]

14. Hogea, S.-P.; Tudorache, E.; Fildan, A.P.; Fira-Mladinescu, O.; Marc, M.; Oancea, C. Risk factors of chronic obstructive pulmonary disease exacerbations. Clin. Respir. J. 2020, 14, 183-197. [CrossRef]

15. Bhowmik, A.; Seemungal, T.A.; Sapsford, R.J.; Wedzicha, J.A. Relation of sputum inflammatory markers to symptoms and lung function changes in COPD exacerbations. Thorax 2000, 55, 114-120. [CrossRef]

16. Bouquet, J.; Tabor, D.E.; Silver, J.S.; Nair, V.; Tovchigrechko, A.; Griffin, M.P.; Esser, M.T.; Sellman, B.R.; Jin, H. Microbial burden and viral exacerbations in a longitudinal multicenter COPD cohort. Respir. Res. 2020, 21, 77. [CrossRef] [PubMed]

17. Beech, A.S.; Lea, S.; Kolsum, U.; Wang, Z.; Miller, B.E.; Donaldson, G.C.; Wedzicha, J.A.; Brightling, C.E.; Singh, D. Bacteria and sputum inflammatory cell counts; a COPD cohort analysis. Respir. Res. 2020, 21, 289. [CrossRef] 
18. Halper-Stromberg, E.; Gillenwater, L.; Cruickshank-Quinn, C.; O’Neal, W.K.; Reisdorph, N.; Petrache, I.; Zhuang, Y.; Labaki, W.W.; Curtis, J.L.; Wells, J.; et al. Bronchoalveolar Lavage Fluid from COPD Patients Reveals More Compounds Associated with Disease than Matched Plasma. Metabolites 2019, 9, 157. [CrossRef]

19. Agudelo, C.W.; Kumley, B.K.; Area-Gomez, E.; Xu, Y.; Dabo, A.J.; Geraghty, P.; Campos, M.; Foronjy, R.; Garcia-Arcos, I. Decreased surfactant lipids correlate with lung function in chronic obstructive pulmonary disease (COPD). PLoS ONE 2020, 15, e0228279. [CrossRef]

20. Telenga, E.D.; Hoffmann, R.F.; Ruben, T.K.; Hoonhorst, S.J.; Willemse, B.W.; van Oosterhout, A.J.; Heijink, I.H.; van den Berge, M.; Jorge, L.; Sandra, P.; et al. Untargeted lipidomic analysis in chronic obstructive pulmonary disease. Uncovering sphingolipids. Am. J. Respir. Crit Care Med. 2014, 190, 155-164. [CrossRef]

21. Ghidoni, R.; Caretti, A.; Signorelli, P. Role of Sphingolipids in the Pathobiology of Lung Inflammation. Mediat. Inflamm. 2015, 2015, 487508. [CrossRef]

22. Gillenwater, L.A.; Kechris, K.J.; Pratte, K.A.; Reisdorph, N.; Petrache, I.; Labaki, W.W.; O’Neal, W.; Krishnan, J.A.; Ortega, V.E.; DeMeo, D.L.; et al. Metabolomic Profiling Reveals Sex Specific Associations with Chronic Obstructive Pulmonary Disease and Emphysema. Metabolites 2021, 11, 161. [CrossRef] [PubMed]

23. Madenspacher, J.H.; Draper, D.W.; Smoak, K.A.; Li, H.; Griffiths, G.L.; Suratt, B.T.; Wilson, M.D.; Rudel, L.L.; Fessler, M.B. Dyslipidemia induces opposing effects on intrapulmonary and extrapulmonary host defense through divergent TLR response phenotypes. J. Immunol. 2010, 185, 1660-1669. [CrossRef] [PubMed]

24. Agudelo, C.W.; Samaha, G.; Garcia-Arcos, I. Alveolar lipids in pulmonary disease. A review. Lipids Health Dis. 2020, 19, 122. [CrossRef]

25. Bernardi, S.; Marcuzzi, A.; Piscianz, E.; Tommasini, A.; Fabris, B. The Complex Interplay between Lipids, Immune System and Interleukins in Cardio-Metabolic Diseases. Int. J. Mol. Sci. 2018, 19, 4058. [CrossRef] [PubMed]

26. Howie, D.; Ten Bokum, A.; Necula, A.S.; Cobbold, S.P.; Waldmann, H. The Role of Lipid Metabolism in T Lymphocyte Differentiation and Survival. Front. Immunol. 2018, 8. [CrossRef]

27. Fernandez-Ruiz, I.; Puchalska, P.; Narasimhulu, C.A.; Sengupta, B.; Parthasarathy, S. Differential lipid metabolism in monocytes and macrophages: Influence of cholesterol loading. J. Lipid Res. 2016, 57, 574-586. [CrossRef]

28. Batista-Gonzalez, A.; Vidal, R.; Criollo, A.; Carreño, L.J. New Insights on the Role of Lipid Metabolism in the Metabolic Reprogramming of Macrophages. Front. Immunol. 2020, 10. [CrossRef]

29. Van den Bossche, J.; O’Neill, L.A.; Menon, D. Macrophage Immunometabolism: Where Are We (Going)? Trends Immunol. 2017, 38, 395-406. [CrossRef]

30. Remmerie, A.; Scott, C.L. Macrophages and lipid metabolism. Cell. Immunol. 2018, 330, 27-42. [CrossRef]

31. Izquierdo, E.; Cuevas, V.D.; Fernández-Arroyo, S.; Riera-Borrull, M.; Orta-Zavalza, E.; Joven, J.; Rial, E.; Corbi, A.L.; Escribese, M.M. Reshaping of Human Macrophage Polarization through Modulation of Glucose Catabolic Pathways. J. Immunol. 2015, 195, 2442-2451. [CrossRef] [PubMed]

32. Agarwal, A.R.; Kadam, S.; Brahme, A.; Agrawal, M.; Apte, K.; Narke, G.; Kekan, K.; Madas, S.; Salvi, S. Systemic Immunometabolic alterations in chronic obstructive pulmonary disease (COPD). Respir. Res. 2019, 20, 171. [CrossRef] [PubMed]

33. Angela, M.; Endo, Y.; Asou, H.K.; Yamamoto, T.; Tumes, D.J.; Tokuyama, H.; Yokote, K.; Nakayama, T. Fatty acid metabolic reprogramming via mTOR-mediated inductions of PPAR $\gamma$ directs early activation of T cells. Nat. Commun. 2016, 7, 13683. [CrossRef] [PubMed]

34. Viola, A.; Munari, F.; Sánchez-Rodríguez, R.; Scolaro, T.; Castegna, A. The Metabolic Signature of Macrophage Responses. Front. Immunol. 2019, 10. [CrossRef] [PubMed]

35. Gong, J.; Zhao, H.; Liu, T.; Li, L.; Cheng, E.; Zhi, S.; Kong, L.; Yao, H.-W.; Li, J. Cigarette Smoke Reduces Fatty Acid Catabolism, Leading to Apoptosis in Lung Endothelial Cells: Implication for Pathogenesis of COPD. Front. Pharmacol. 2019, 10. [CrossRef] [PubMed]

36. Ween, M.P.; White, J.B.; Tran, H.B.; Mukaro, V.; Jones, C.; Macowan, M.; Hodge, G.; Trim, P.J.; Snel, M.F.; Hodge, S.J. The role of oxidised self-lipids and alveolar macrophage CD1b expression in COPD. Sci. Rep. 2021, 11, 4106. [CrossRef] [PubMed]

37. Davies, P.; Sornberger, G.C.; Huber, G.L. The stereology of pulmonary alveolar macrophages after prolonged experimental exposure to tobacco smoke. Lab. Investig. 1977, 37, 297-306.

38. Hannan, S.E.; Harris, J.O.; Sheridan, N.P.; Patel, J.M. Cigarette smoke alters plasma membrane fluidity of rat alveolar macrophages. Am. Rev. Respir. Dis. 1989, 140, 1668-1673. [CrossRef]

39. Van der Does, A.M.; Heijink, M.; Mayboroda, O.A.; Persson, L.J.; Aanerud, M.; Bakke, P.; Eagan, T.M.; Hiemstra, P.S.; Giera, M. Dynamic differences in dietary polyunsaturated fatty acid metabolism in sputum of COPD patients and controls. Biochim. Biophys. Acta BBA Mol. Cell Biol. Lipids 2019, 1864, 224-233. [CrossRef]

40. Van der Does, A.M.; Heijink, M.; Persson, L.J.; Kloos, D.-P.; Aanerud, M.; Bakke, P.; Taube, C.; Eagan, T.; Hiemstra, P.S.; Giera, M. Disturbed fatty acid metabolism in airway secretions of patients with Chronic Obstructive Pulmonary Disease. Eur. Respir. J. 2017, 50, PA3913. [CrossRef]

41. Das, U.N. Arachidonic acid and other unsaturated fatty acids and some of their metabolites function as endogenous antimicrobial molecules: A review. J. Adv. Res. 2018, 11, 57-66. [CrossRef] 
42. Rutting, S.; Papanicolaou, M.; Xenaki, D.; Wood, L.G.; Mullin, A.M.; Hansbro, P.M.; Oliver, B.G. Dietary $\omega-6$ polyunsaturated fatty acid arachidonic acid increases inflammation, but inhibits ECM protein expression in COPD. Respir. Res. 2018, 19, 211. [CrossRef]

43. Gutiérrez, S.; Svahn, S.L.; Johansson, M.E. Effects of Omega-3 Fatty Acids on Immune Cells. Int. J. Mol. Sci. 2019, 20, 5028. [CrossRef]

44. Simons, K.; Gerl, M.J. Revitalizing membrane rafts: New tools and insights. Nat. Rev. Mol. Cell Biol. 2010, 11, 688-699. [CrossRef] [PubMed]

45. Tsai, Y.-H.; Chen, W.-L. Host Lipid Rafts as the Gates for Listeria monocytogenes Infection: A Mini-Review. Front. Immunol. 2020, 11. [CrossRef] [PubMed]

46. Sezgin, E.; Levental, I.; Mayor, S.; Eggeling, C. The mystery of membrane organization: Composition, regulation and roles of lipid rafts. Nat. Rev. Mol. Cell Biol. 2017, 18, 361-374. [CrossRef] [PubMed]

47. Simons, K.; Ikonen, E. Functional rafts in cell membranes. Nature 1997, 387, 569-572. [CrossRef] [PubMed]

48. Ouweneel, A.B.; Thomas, M.J.; Sorci-Thomas, M.G. The ins and outs of lipid rafts: Functions in intracellular cholesterol homeostasis, microparticles, and cell membranes: Thematic Review Series: Biology of Lipid Rafts. J. Lipid Res. 2020, 61, 676-686. [CrossRef]

49. Fantini, J.; Barrantes, F.J. How cholesterol interacts with membrane proteins: An exploration of cholesterol-binding sites including CRAC, CARC, and tilted domains. Front. Physiol. 2013, 4, 31. [CrossRef]

50. Fantini, J.; Epand, R.M.; Barrantes, F.J. Cholesterol-Recognition Motifs in Membrane Proteins. Adv. Exp. Med. Biol. 2019, 1135, 3-25. [CrossRef]

51. Bieberich, E. Sphingolipids and lipid rafts: Novel concepts and methods of analysis. Chem. Phys. Lipids 2018, 216, 114-131. [CrossRef]

52. Hellwing, C.; Tigistu-Sahle, F.; Fuhrmann, H.; Käkelä, R.; Schumann, J. Lipid composition of membrane microdomains isolated detergent-free from PUFA supplemented RAW264.7 macrophages. J. Cell. Physiol. 2018, 233, 2602-2612. [CrossRef]

53. Hansen, C.G.; Nichols, B.J. Exploring the caves: Cavins, caveolins and caveolae. Trends Cell Biol. 2010, 20, 177-186. [CrossRef] [PubMed]

54. Liu, P.; Rudick, M.; Anderson, R.G. Multiple functions of caveolin-1. J. Biol. Chem. 2002, 277, 41295-41298. [CrossRef] [PubMed]

55. Thomas, C.M.; Smart, E.J. Caveolae structure and function. J. Cell. Mol. Med. 2008, 12, 796-809. [CrossRef] [PubMed]

56. Jin, Y.; Lee, S.J.; Minshall, R.D.; Choi, A.M. Caveolin-1: A critical regulator of lung injury. Am. J. Physiol. Lung Cell. Mol. Physiol. 2011, 300, L151-L160. [CrossRef]

57. Zaas, D.W.; Duncan, M.; Rae Wright, J.; Abraham, S.N. The role of lipid rafts in the pathogenesis of bacterial infections. Biochim. Biophys. Acta BBA Mol. Cell Res. 2005, 1746, 305-313. [CrossRef] [PubMed]

58. Stan, R.V. Structure of caveolae. Biochim. Biophys. Acta 2005, 1746, 334-348. [CrossRef]

59. Yu, Q.; Chen, X.; Fang, X.; Chen, Q.; Hu, C. Caveolin-1 aggravates cigarette smoke extract-induced MUC5AC secretion in human airway epithelial cells. Int. J. Mol. Med. 2015, 35, 1435-1442. [CrossRef]

60. Pike, L.J. Rafts defined: A report on the Keystone Symposium on Lipid Rafts and Cell Function. J. Lipid Res. 2006, 47, 1597-1598. [CrossRef]

61. Predescu, S.A.; Predescu, D.N.; Malik, A.B. Molecular determinants of endothelial transcytosis and their role in endothelial permeability. Am. J. Physiol. Lung Cell. Mol. Physiol. 2007, 293, L823-L842. [CrossRef] [PubMed]

62. Wang, Z.; Tiruppathi, C.; Minshall, R.D.; Malik, A.B. Size and dynamics of caveolae studied using nanoparticles in living endothelial cells. ACS Nano 2009, 3, 4110-4116. [CrossRef] [PubMed]

63. Anderson, R.G. The caveolae membrane system. Annu. Rev. Biochem. 1998, 67, 199-225. [CrossRef]

64. Fielding, C.J.; Fielding, P.E. Relationship between cholesterol trafficking and signaling in rafts and caveolae. Biochim. Biophys. Acta BBA Biomembr. 2003, 1610, 219-228. [CrossRef]

65. Drab, M.; Verkade, P.; Elger, M.; Kasper, M.; Lohn, M.; Lauterbach, B.; Menne, J.; Lindschau, C.; Mende, F.; Luft, F.C.; et al. Loss of caveolae, vascular dysfunction, and pulmonary defects in caveolin-1 gene-disrupted mice. Science 2001, 293, $2449-2452$. [CrossRef]

66. Garrean, S.; Gao, X.P.; Brovkovych, V.; Shimizu, J.; Zhao, Y.Y.; Vogel, S.M.; Malik, A.B. Caveolin-1 regulates NF-kappaB activation and lung inflammatory response to sepsis induced by lipopolysaccharide. J. Immunol. 2006, 177, 4853-4860. [CrossRef]

67. Epand, R.M.; Sayer, B.G.; Epand, R.F. Caveolin Scaffolding Region and Cholesterol-rich Domains in Membranes. J. Mol. Biol. 2005, 345, 339-350. [CrossRef]

68. Sohn, J.; Lin, H.; Fritch, M.R.; Tuan, R.S. Influence of cholesterol/caveolin-1/caveolae homeostasis on membrane properties and substrate adhesion characteristics of adult human mesenchymal stem cells. Stem Cell Res. Ther. 2018, 9, 86. [CrossRef]

69. Kotlyarov, S.; Kotlyarova, A. The Role of ABC Transporters in Lipid Metabolism and the Comorbid Course of Chronic Obstructive Pulmonary Disease and Atherosclerosis. Int. J. Mol. Sci. 2021, 22, 6711. [CrossRef]

70. Ouimet, M.; Barrett, T.J.; Fisher, E.A. HDL and Reverse Cholesterol Transport. Circ. Res. 2019, 124, 1505-1518. [CrossRef]

71. Song, W.; Wang, W.; Dou, L.Y.; Wang, Y.; Xu, Y.; Chen, L.F.; Yan, X.W. The implication of cigarette smoking and cessation on macrophage cholesterol efflux in coronary artery disease patients. J. Lipid Res. 2015, 56, 682-691. [CrossRef] [PubMed] 
72. Sonett, J.; Goldklang, M.; Sklepkiewicz, P.; Gerber, A.; Trischler, J.; Zelonina, T.; Westerterp, M.; Lemaître, V.; Okada, Y.; $\mathrm{D}^{\prime}$ Armiento, J. A critical role for ABC transporters in persistent lung inflammation in the development of emphysema after smoke exposure. FASEB J 2018, 32, 6724-6736. [CrossRef]

73. Draper, D.W.; Madenspacher, J.H.; Dixon, D.; King, D.H.; Remaley, A.T.; Fessler, M.B. ATP-binding cassette transporter G1 deficiency dysregulates host defense in the lung. Am. J. Respir. Crit. Care Med. 2010, 182, 404-412. [CrossRef] [PubMed]

74. Korhonen, J.T.; Olkkonen, V.M.; Lahesmaa, R.; Puolakkainen, M. ABC-cassette transporter 1 (ABCA1) expression in epithelial cells in Chlamydia pneumoniae infection. Microb. Pathog. 2013, 61-62, 57-61. [CrossRef] [PubMed]

75. Wu, A.; Wojtowicz, K.; Savary, S.; Hamon, Y.; Trombik, T. Do ABC transporters regulate plasma membrane organization? Cell. Mol. Biol. Lett. 2020, 25, 37. [CrossRef]

76. Chambenoit, O.; Hamon, Y.; Marguet, D.; Rigneault, H.; Rosseneu, M.; Chimini, G. Specific docking of apolipoprotein A-I at the cell surface requires a functional ABCA1 transporter. J. Biol. Chem. 2001, 276, 9955-9960. [CrossRef]

77. Hamon, Y.; Broccardo, C.; Chambenoit, O.; Luciani, M.F.; Toti, F.; Chaslin, S.; Freyssinet, J.M.; Devaux, P.F.; McNeish, J.; Marguet, D.; et al. ABC1 promotes engulfment of apoptotic cells and transbilayer redistribution of phosphatidylserine. Nat. Cell Biol. 2000, 2, 399-406. [CrossRef]

78. Rigot, V.; Hamon, Y.; Chambenoit, O.; Alibert, M.; Duverger, N.; Chimini, G. Distinct sites on ABCA1 control distinct steps required for cellular release of phospholipids. J. Lipid Res. 2002, 43, 2077-2086. [CrossRef]

79. Alder-Baerens, N.; Müller, P.; Pohl, A.; Korte, T.; Hamon, Y.; Chimini, G.; Pomorski, T.; Herrmann, A. Headgroup-specific exposure of phospholipids in ABCA1-expressing cells. J. Biol. Chem. 2005, 280, 26321-26329. [CrossRef]

80. Landry, Y.D.; Denis, M.; Nandi, S.; Bell, S.; Vaughan, A.M.; Zha, X. ATP-binding cassette transporter A1 expression disrupts raft membrane microdomains through its ATPase-related functions. J. Biol. Chem. 2006, 281, 36091-36101. [CrossRef]

81. Zarubica, A.; Plazzo, A.P.; Stöckl, M.; Trombik, T.; Hamon, Y.; MÜller, P.; Pomorski, T.; Herrmann, A.; Chimini, G. Functional implications of the influence of ABCA1 on lipid microenvironment at the plasma membrane: A biophysical study. FASEB J. 2009, 23, 1775-1785. [CrossRef] [PubMed]

82. Koseki, M.; Hirano, K.; Masuda, D.; Ikegami, C.; Tanaka, M.; Ota, A.; Sandoval, J.C.; Nakagawa-Toyama, Y.; Sato, S.B.; Kobayashi, T.; et al. Increased lipid rafts and accelerated lipopolysaccharide-induced tumor necrosis factor-alpha secretion in Abca1-deficient macrophages. J. Lipid Res. 2007, 48, 299-306. [CrossRef] [PubMed]

83. McGillicuddy, F.C.; de la Llera Moya, M.; Hinkle, C.C.; Joshi, M.R.; Chiquoine, E.H.; Billheimer, J.T.; Rothblat, G.H.; Reilly, M.P. Inflammation impairs reverse cholesterol transport in vivo. Circulation 2009, 119, 1135-1145. [CrossRef]

84. Faure, K.; Sawa, T.; Ajayi, T.; Fujimoto, J.; Moriyama, K.; Shime, N.; Wiener-Kronish, J.P. TLR4 signaling is essential for survival in acute lung injury induced by virulent Pseudomonas aeruginosa secreting type III secretory toxins. Respir. Res. $2004,5,1$. [CrossRef] [PubMed]

85. Basu, S.; Fenton, M.J. Toll-like receptors: Function and roles in lung disease. Am. J. Physiol. Lung Cell. Mol. Physiol. 2004, 286, L887-L892. [CrossRef]

86. Zhang, X.; Shan, P.; Jiang, G.; Cohn, L.; Lee, P.J. Toll-like receptor 4 deficiency causes pulmonary emphysema. J. Clin. Investig. 2006, 116, 3050-3059. [CrossRef]

87. Zhang, X.; Shan, P.; Qureshi, S.; Homer, R.; Medzhitov, R.; Noble, P.W.; Lee, P.J. Cutting edge: TLR4 deficiency confers susceptibility to lethal oxidant lung injury. J. Immunol. 2005, 175, 4834-4838. [CrossRef] [PubMed]

88. Sarir, H.; Mortaz, E.; Karimi, K.; Kraneveld, A.D.; Rahman, I.; Caldenhoven, E.; Nijkamp, F.P.; Folkerts, G. Cigarette smoke regulates the expression of TLR4 and IL-8 production by human macrophages. J. Inflamm. 2009, 6, 12. [CrossRef]

89. Karimi, K.; Sarir, H.; Mortaz, E.; Smit, J.J.; Hosseini, H.; De Kimpe, S.J.; Nijkamp, F.P.; Folkerts, G. Toll-like receptor-4 mediates cigarette smoke-induced cytokine production by human macrophages. Respir. Res. 2006, 7, 66. [CrossRef]

90. Ruysschaert, J.M.; Lonez, C. Role of lipid microdomains in TLR-mediated signalling. Biochim. Biophys. Acta 2015, 1848, $1860-1867$. [CrossRef]

91. Kotlyarov, S. Participation of ABCA1 Transporter in Pathogenesis of Chronic Obstructive Pulmonary Disease. Int. J. Mol. Sci. 2021, 22, 3334. [CrossRef] [PubMed]

92. Zhu, X.; Owen, J.S.; Wilson, M.D.; Li, H.; Griffiths, G.L.; Thomas, M.J.; Hiltbold, E.M.; Fessler, M.B.; Parks, J.S. Macrophage ABCA1 reduces MyD88-dependent Toll-like receptor trafficking to lipid rafts by reduction of lipid raft cholesterol. J. Lipid Res. 2010, 51, 3196-3206. [CrossRef]

93. Frisdal, E.; Lesnik, P.; Olivier, M.; Robillard, P.; Chapman, M.J.; Huby, T.; Guerin, M.; Le Goff, W. Interleukin-6 protects human macrophages from cellular cholesterol accumulation and attenuates the proinflammatory response. J. Biol. Chem. 2011, 286, 30926-30936. [CrossRef] [PubMed]

94. Castrillo, A.; Joseph, S.B.; Vaidya, S.A.; Haberland, M.; Fogelman, A.M.; Cheng, G.; Tontonoz, P. Crosstalk between LXR and toll-like receptor signaling mediates bacterial and viral antagonism of cholesterol metabolism. Mol. Cell 2003, 12, 805-816. [CrossRef]

95. Kleinridders, A.; Schenten, D.; Konner, A.C.; Belgardt, B.F.; Mauer, J.; Okamura, T.; Wunderlich, F.T.; Medzhitov, R.; Bruning, J.C. MyD88 signaling in the CNS is required for development of fatty acid-induced leptin resistance and diet-induced obesity. Cell Metab. 2009, 10, 249-259. [CrossRef]

96. Lee, J.Y.; Sohn, K.H.; Rhee, S.H.; Hwang, D. Saturated fatty acids, but not unsaturated fatty acids, induce the expression of cyclooxygenase-2 mediated through Toll-like receptor 4. J. Biol. Chem. 2001, 276, 16683-16689. [CrossRef] [PubMed] 
97. Rogero, M.M.; Calder, P.C. Obesity, Inflammation, Toll-Like Receptor 4 and Fatty Acids. Nutrients 2018, 10, 432. [CrossRef]

98. Hoshino, K.; Takeuchi, O.; Kawai, T.; Sanjo, H.; Ogawa, T.; Takeda, Y.; Takeda, K.; Akira, S. Cutting edge: Toll-like receptor 4 (TLR4)-deficient mice are hyporesponsive to lipopolysaccharide: Evidence for TLR4 as the Lps gene product. J. Immunol. 1999, 162, 3749-3752.

99. Cantin, A.M. Cellular response to cigarette smoke and oxidants: Adapting to survive. Proc. Am. Thorac. Soc. 2010, 7, 368-375. [CrossRef]

100. Lundström, S.L.; Balgoma, D.; Wheelock, Å.M.; Haeggström, J.Z.; Dahlén, S.E.; Wheelock, C.E. Lipid mediator profiling in pulmonary disease. Curr. Pharm. Biotechnol. 2011, 12, 1026-1052. [CrossRef]

101. Petrache, I.; Natarajan, V.; Zhen, L.; Medler, T.R.; Richter, A.T.; Cho, C.; Hubbard, W.C.; Berdyshev, E.V.; Tuder, R.M. Ceramide upregulation causes pulmonary cell apoptosis and emphysema-like disease in mice. Nat. Med. 2005, 11, 491-498. [CrossRef] [PubMed]

102. Scarpa, M.C.; Baraldo, S.; Marian, E.; Turato, G.; Calabrese, F.; Saetta, M.; Maestrelli, P. Ceramide expression and cell homeostasis in chronic obstructive pulmonary disease. Respiration 2013, 85, 342-349. [CrossRef]

103. Fischer, H.; Ellström, P.; Ekström, K.; Gustafsson, L.; Gustafsson, M.; Svanborg, C. Ceramide as a TLR4 agonist; a putative signalling intermediate between sphingolipid receptors for microbial ligands and TLR4. Cell. Microbiol. 2007, 9, 1239-1251. [CrossRef] [PubMed]

104. Svanborg, C.; Frendéus, B.; Godaly, G.; Hang, L.; Hedlund, M.; Wachtler, C. Toll-like receptor signaling and chemokine receptor expression influence the severity of urinary tract infection. J. Infect. Dis. 2001, 183 (Suppl. 1), S61-S65. [CrossRef]

105. Joseph, C.K.; Wright, S.D.; Bornmann, W.G.; Randolph, J.T.; Kumar, E.R.; Bittman, R.; Liu, J.; Kolesnick, R.N. Bacterial lipopolysaccharide has structural similarity to ceramide and stimulates ceramide-activated protein kinase in myeloid cells. J. Biol. Chem. 1994, 269, 17606-17610. [CrossRef]

106. Cuschieri, J.; Bulger, E.; Billgrin, J.; Garcia, I.; Maier, R.V. Acid sphingomyelinase is required for lipid Raft TLR4 complex formation. Surg. Infect. 2007, 8, 91-106. [CrossRef] [PubMed]

107. MacKichan, M.L.; DeFranco, A.L. Role of ceramide in lipopolysaccharide (LPS)-induced signaling. LPS increases ceramide rather than acting as a structural homolog. J. Biol. Chem. 1999, 274, 1767-1775. [CrossRef]

108. Jin, J.; Zhang, X.; Lu, Z.; Perry, D.M.; Li, Y.; Russo, S.B.; Cowart, L.A.; Hannun, Y.A.; Huang, Y. Acid sphingomyelinase plays a key role in palmitic acid-amplified inflammatory signaling triggered by lipopolysaccharide at low concentrations in macrophages. Am. J. Physiol. Endocrinol. Metab. 2013, 305, E853-E867. [CrossRef]

109. Jin, J.; Lu, Z.; Li, Y.; Cowart, L.A.; Lopes-Virella, M.F.; Huang, Y. Docosahexaenoic acid antagonizes the boosting effect of palmitic acid on LPS inflammatory signaling by inhibiting gene transcription and ceramide synthesis. PLoS ONE 2018, 13, e0193343. [CrossRef]

110. Petrusca, D.N.; Gu, Y.; Adamowicz, J.J.; Rush, N.I.; Hubbard, W.C.; Smith, P.A.; Berdyshev, E.V.; Birukov, K.G.; Lee, C.-H.; Tuder, R.M.; et al. Sphingolipid-mediated inhibition of apoptotic cell clearance by alveolar macrophages. J. Biol. Chem. 2010, 285, 40322-40332. [CrossRef]

111. Sze, M.A.; Hogg, J.C.; Sin, D.D. Bacterial microbiome of lungs in COPD. Int. J. Chronic Obs. Pulm. Dis 2014, 9, 229-238. [CrossRef]

112. Cookson, W.O.C.M.; Cox, M.J.; Moffatt, M.F. New opportunities for managing acute and chronic lung infections. Nat. Rev. Microbiol. 2018, 16, 111-120. [CrossRef] [PubMed]

113. Su, Y.-C.; Jalalvand, F.; Thegerström, J.; Riesbeck, K. The Interplay Between Immune Response and Bacterial Infection in COPD: Focus Upon Non-typeable Haemophilus influenzae. Front. Immunol. 2018, 9. [CrossRef] [PubMed]

114. Charlson, E.S.; Bittinger, K.; Haas, A.R.; Fitzgerald, A.S.; Frank, I.; Yadav, A.; Bushman, F.D.; Collman, R.G. Topographical continuity of bacterial populations in the healthy human respiratory tract. Am. J. Respir. Crit. Care Med. 2011, 184, 957-963. [CrossRef] [PubMed]

115. Dickson, R.P.; Erb-Downward, J.R.; Freeman, C.M.; McCloskey, L.; Falkowski, N.R.; Huffnagle, G.B.; Curtis, J.L. Bacterial Topography of the Healthy Human Lower Respiratory Tract. mBio 2017, 8, e02287-16. [CrossRef]

116. Erb-Downward, J.R.; Thompson, D.L.; Han, M.K.; Freeman, C.M.; McCloskey, L.; Schmidt, L.A.; Young, V.B.; Toews, G.B.; Curtis, J.L.; Sundaram, B.; et al. Analysis of the lung microbiome in the "healthy" smoker and in COPD. PLoS ONE 2011, 6, e16384. [CrossRef]

117. Hilty, M.; Burke, C.; Pedro, H.; Cardenas, P.; Bush, A.; Bossley, C.; Davies, J.; Ervine, A.; Poulter, L.; Pachter, L.; et al. Disordered microbial communities in asthmatic airways. PLoS ONE 2010, 5, e8578. [CrossRef]

118. Charlson, E.S.; Bittinger, K.; Chen, J.; Diamond, J.M.; Li, H.; Collman, R.G.; Bushman, F.D. Assessing bacterial populations in the lung by replicate analysis of samples from the upper and lower respiratory tracts. PLoS ONE 2012, 7, e42786. [CrossRef]

119. Ubags, N.D.J.; Marsland, B.J. Mechanistic insight into the function of the microbiome in lung diseases. Eur. Respir. J. 2017, 50, 1602467. [CrossRef]

120. Dickson, R.P.; Erb-Downward, J.R.; Freeman, C.M.; McCloskey, L.; Beck, J.M.; Huffnagle, G.B.; Curtis, J.L. Spatial Variation in the Healthy Human Lung Microbiome and the Adapted Island Model of Lung Biogeography. Ann. Am. Thorac. Soc. 2015, 12, 821-830. [CrossRef]

121. Venkataraman, A.; Bassis, C.M.; Beck, J.M.; Young, V.B.; Curtis, J.L.; Huffnagle, G.B.; Schmidt, T.M. Application of a neutral community model to assess structuring of the human lung microbiome. mBio 2015, 6, e02284-14. [CrossRef] 
122. Willner, D.; Haynes, M.R.; Furlan, M.; Schmieder, R.; Lim, Y.W.; Rainey, P.B.; Rohwer, F.; Conrad, D. Spatial distribution of microbial communities in the cystic fibrosis lung. ISME J 2012, 6, 471-474. [CrossRef]

123. Man, W.H.; de Steenhuijsen Piters, W.A.A.; Bogaert, D. The microbiota of the respiratory tract: Gatekeeper to respiratory health. Nat. Rev. Microbiol. 2017, 15, 259-270. [CrossRef]

124. Huffnagle, G.B.; Dickson, R.P.; Lukacs, N.W. The respiratory tract microbiome and lung inflammation: A two-way street. Mucosal Immunol. 2017, 10, 299-306. [CrossRef]

125. Leopold, P.L.; O’Mahony, M.J.; Lian, X.J.; Tilley, A.E.; Harvey, B.G.; Crystal, R.G. Smoking is associated with shortened airway cilia. PLoS ONE 2009, 4, e8157. [CrossRef] [PubMed]

126. Foster, W.M.; Costa, D.L.; Langenback, E.G. Ozone exposure alters tracheobronchial mucociliary function in humans. J. Appl. Physiol. 1987, 63, 996-1002. [CrossRef] [PubMed]

127. Segal, L.N.; Clemente, J.C.; Tsay, J.-C.J.; Koralov, S.B.; Keller, B.C.; Wu, B.G.; Li, Y.; Shen, N.; Ghedin, E.; Morris, A.; et al. Enrichment of the lung microbiome with oral taxa is associated with lung inflammation of a Th17 phenotype. Nat. Microbiol. 2016, 1, 16031. [CrossRef] [PubMed]

128. Pragman, A.A.; Lyu, T.; Baller, J.A.; Gould, T.J.; Kelly, R.F.; Reilly, C.S.; Isaacson, R.E.; Wendt, C.H. The lung tissue microbiota of mild and moderate chronic obstructive pulmonary disease. Microbiome 2018, 6, 7. [CrossRef] [PubMed]

129. Bassis, C.M.; Erb-Downward, J.R.; Dickson, R.P.; Freeman, C.M.; Schmidt, T.M.; Young, V.B.; Beck, J.M.; Curtis, J.L.; Huffnagle, G.B. Analysis of the Upper Respiratory Tract Microbiotas as the Source of the Lung and Gastric Microbiotas in Healthy Individuals mBio 2015, 6, e00037-15. [CrossRef]

130. Rivera-Chavez, F.; Winter, S.E.; Lopez, C.A.; Xavier, M.N.; Winter, M.G.; Nuccio, S.P.; Russell, J.M.; Laughlin, R.C.; Lawhon, S.D.; Sterzenbach, T.; et al. Salmonella uses energy taxis to benefit from intestinal inflammation. PLoS Pathog. 2013, 9, e1003267. [CrossRef]

131. Dickson, R.P.; Erb-Downward, J.R.; Huffnagle, G.B. The role of the bacterial microbiome in lung disease. Expert Rev. Respir. Med. 2013, 7, 245-257. [CrossRef]

132. Segal, L.N.; Alekseyenko, A.V.; Clemente, J.C.; Kulkarni, R.; Wu, B.; Gao, Z.; Chen, H.; Berger, K.I.; Goldring, R.M.; Rom, W.N.; et al. Enrichment of lung microbiome with supraglottic taxa is associated with increased pulmonary inflammation. Microbiome 2013, 1, 19. [CrossRef]

133. Morris, A.; Beck, J.M.; Schloss, P.D.; Campbell, T.B.; Crothers, K.; Curtis, J.L.; Flores, S.C.; Fontenot, A.P.; Ghedin, E.; Huang, L.; et al. Comparison of the respiratory microbiome in healthy nonsmokers and smokers. Am. J. Respir. Crit. Care Med. 2013, 187, 1067-1075. [CrossRef] [PubMed]

134. Brown, R.L.; Sequeira, R.P.; Clarke, T.B. The microbiota protects against respiratory infection via GM-CSF signaling. Nat. Commun. 2017, 8, 1512. [CrossRef] [PubMed]

135. Mayhew, D.; Devos, N.; Lambert, C.; Brown, J.R.; Clarke, S.C.; Kim, V.L.; Magid-Slav, M.; Miller, B.E.; Ostridge, K.K.; Patel, R.; et al. Longitudinal profiling of the lung microbiome in the AERIS study demonstrates repeatability of bacterial and eosinophilic COPD exacerbations. Thorax 2018, 73, 422-430. [CrossRef]

136. Molyneaux, P.L.; Mallia, P.; Cox, M.J.; Footitt, J.; Willis-Owen, S.A.; Homola, D.; Trujillo-Torralbo, M.B.; Elkin, S.; Kon, O.M.; Cookson, W.O.; et al. Outgrowth of the bacterial airway microbiome after rhinovirus exacerbation of chronic obstructive pulmonary disease. Am. J. Respir. Crit. Care Med. 2013, 188, 1224-1231. [CrossRef] [PubMed]

137. Engel, M.; Endesfelder, D.; Schloter-Hai, B.; Kublik, S.; Granitsiotis, M.S.; Boschetto, P.; Stendardo, M.; Barta, I.; Dome, B.; Deleuze, J.F.; et al. Influence of lung CT changes in chronic obstructive pulmonary disease (COPD) on the human lung microbiome. PLoS ONE 2017, 12, e0180859. [CrossRef]

138. Tangedal, S.; Aanerud, M.; Grønseth, R.; Drengenes, C.; Wiker, H.G.; Bakke, P.S.; Eagan, T.M. Comparing microbiota profiles in induced and spontaneous sputum samples in COPD patients. Respir. Res. 2017, 18, 164. [CrossRef]

139. Diao, W.; Shen, N.; Du, Y.; Qian, K.; He, B. Characterization of throat microbial flora in smokers with or without COPD. Int. J. Chronic Obs. Pulm. Dis. 2017, 12, 1933-1946. [CrossRef]

140. Garcia-Nuñez, M.; Millares, L.; Pomares, X.; Ferrari, R.; Pérez-Brocal, V.; Gallego, M.; Espasa, M.; Moya, A.; Monsó, E. SeverityRelated Changes of Bronchial Microbiome in Chronic Obstructive Pulmonary Disease. J. Clin. Microbiol. 2014, 52, 4217-4223. [CrossRef]

141. Huang, Y.J.; Sethi, S.; Murphy, T.; Nariya, S.; Boushey, H.A.; Lynch, S.V. Airway Microbiome Dynamics in Exacerbations of Chronic Obstructive Pulmonary Disease. J. Clin. Microbiol. 2014, 52, 2813-2823. [CrossRef]

142. Jubinville, E.; Veillette, M.; Milot, J.; Maltais, F.; Comeau, A.M.; Levesque, R.C.; Duchaine, C. Exacerbation induces a microbiota shift in sputa of COPD patients. PLoS ONE 2018, 13, e0194355. [CrossRef]

143. Sapey, E.; Stockley, R.A. COPD exacerbations · 2: Aetiology. Thorax 2006, 61, 250-258. [CrossRef]

144. Celli, B.R.; Barnes, P.J. Exacerbations of chronic obstructive pulmonary disease. Eur. Respir. J. 2007, 29, 1224-1238. [CrossRef]

145. Chang, C.L.; Sullivan, G.D.; Karalus, N.C.; Mills, G.D.; Mclachlan, J.D.; Hancox, R.J. Predicting early mortality in acute exacerbation of chronic obstructive pulmonary disease using the CURB65 score. Respirology 2011, 16, 146-151. [CrossRef] [PubMed]

146. Lou, P.; Zhu, Y.; Chen, P.; Zhang, P.; Yu, J.; Zhang, N.; Chen, N.; Zhang, L.; Wu, H.; Zhao, J. Vulnerability, beliefs, treatments and economic burden of chronic obstructive pulmonary disease in rural areas in China: A cross-sectional study. BMC Public Health 2012, 12, 287. [CrossRef] 
147. Rosell, A.; Monsó, E.; Soler, N.; Torres, F.; Angrill, J.; Riise, G.; Zalacaín, R.; Morera, J.; Torres, A. Microbiologic Determinants of Exacerbation in Chronic Obstructive Pulmonary Disease. Arch. Intern. Med. 2005, 165, 891-897. [CrossRef] [PubMed]

148. Kuwal, A.; Joshi, V.; Dutt, N.; Singh, S.; Agarwal, K.C.; Purohit, G. A Prospective Study of Bacteriological Etiology in Hospitalized Acute Exacerbation of COPD Patients: Relationship with Lung Function and Respiratory Failure. Turk. Thorac. J. 2018, 19, 19-27. [CrossRef] [PubMed]

149. Sethi, S.; Murphy, T.F. Infection in the pathogenesis and course of chronic obstructive pulmonary disease. N. Engl. J. Med. 2008, 359, 2355-2365. [CrossRef]

150. Wedzicha, J.A.; Seemungal, T.A. COPD exacerbations: Defining their cause and prevention. Lancet 2007, 370, 786-796. [CrossRef]

151. Ko, F.W.; Chan, K.P.; Hui, D.S.; Goddard, J.R.; Shaw, J.G.; Reid, D.W.; Yang, I.A. Acute exacerbation of COPD. Respirology 2016, 21, 1152-1165. [CrossRef]

152. Wilkinson, T.M.A.; Aris, E.; Bourne, S.; Clarke, S.C.; Peeters, M.; Pascal, T.G.; Schoonbroodt, S.; Tuck, A.C.; Kim, V.; Ostridge, K.; et al. A prospective, observational cohort study of the seasonal dynamics of airway pathogens in the aetiology of exacerbations in COPD. Thorax 2017, 72, 919-927. [CrossRef] [PubMed]

153. Wang, Z.; Bafadhel, M.; Haldar, K.; Spivak, A.; Mayhew, D.; Miller, B.E.; Tal-Singer, R.; Johnston, S.L.; Ramsheh, M.Y.; Barer, M.R.; et al. Lung microbiome dynamics in COPD exacerbations. Eur. Respir. J. 2016, 47, 1082-1092. [CrossRef]

154. Polverino, E.; Rosales-Mayor, E.; Benegas, M.; Menendez, R.; Alcaraz-Serrano, V.; Ansotegui, E.; Montull, B.; Giron, R.M.; Cisneros, C.; Vendrell, M.; et al. Pneumonic and non-pneumonic exacerbations in bronchiectasis: Clinical and microbiological differences. J. Infect. 2018, 77, 99-106. [CrossRef]

155. Simpson, J.L.; Baines, K.J.; Horvat, J.C.; Essilfie, A.-T.; Brown, A.C.; Tooze, M.; McDonald, V.M.; Gibson, P.G.; Hansbro, P.M. COPD is characterized by increased detection of Haemophilus influenzae, Streptococcus pneumoniae and a deficiency of Bacillus species. Respirology 2016, 21, 697-704. [CrossRef]

156. Soler, N.; Torres, A.; Ewig, S.; Gonzalez, J.; Celis, R.; El-Ebiary, M.; Hernandez, C.; Rodriguez-Roisin, R. Bronchial microbial patterns in severe exacerbations of chronic obstructive pulmonary disease (COPD) requiring mechanical ventilation. Am. J. Respir. Crit. Care Med. 1998, 157, 1498-1505. [CrossRef]

157. Bogaert, D.; van der Valk, P.; Ramdin, R.; Sluijter, M.; Monninkhof, E.; Hendrix, R.; de Groot, R.; Hermans, P.W.M. Host-Pathogen Interaction during Pneumococcal Infection in Patients with Chronic Obstructive Pulmonary Disease. Infect. Immun. 2004, 72, 818-823. [CrossRef] [PubMed]

158. Yao, J.; Rock, C.O. How bacterial pathogens eat host lipids: Implications for the development of fatty acid synthesis therapeutics. J. Biol. Chem. 2015, 290, 5940-5946. [CrossRef] [PubMed]

159. Fozo, E.M.; Rucks, E.A. The Making and Taking of Lipids: The Role of Bacterial Lipid Synthesis and the Harnessing of Host Lipids in Bacterial Pathogenesis. Adv. Microb. Physiol. 2016, 69, 51-155. [CrossRef]

160. Hinkel, L.A.; Wargo, M.J. Participation of Bacterial Lipases, Sphingomyelinases, and Phospholipases in Gram-Negative Bacterial Pathogenesis. In Health Consequences of Microbial Interactions with Hydrocarbons, Oils, and Lipids; Goldfine, H., Ed.; Springer International Publishing: Cham, Switzerland, 2020; pp. 181-203.

161. Sun, Z.; Kang, Y.; Norris, M.H.; Troyer, R.M.; Son, M.S.; Schweizer, H.P.; Dow, S.W.; Hoang, T.T. Blocking phosphatidylcholine utilization in Pseudomonas aeruginosa, via mutagenesis of fatty acid, glycerol and choline degradation pathways, confirms the importance of this nutrient source in vivo. PLoS ONE 2014, 9, e103778. [CrossRef] [PubMed]

162. Son, M.S.; Matthews, W.J., Jr.; Kang, Y.; Nguyen, D.T.; Hoang, T.T. In vivo evidence of Pseudomonas aeruginosa nutrient acquisition and pathogenesis in the lungs of cystic fibrosis patients. Infect. Immun. 2007, 75, 5313-5324. [CrossRef]

163. Zarzycki-Siek, J.; Norris, M.H.; Kang, Y.; Sun, Z.; Bluhm, A.P.; McMillan, I.A.; Hoang, T.T. Elucidating the Pseudomonas aeruginosa fatty acid degradation pathway: Identification of additional fatty acyl-CoA synthetase homologues. PLoS ONE 2013, 8, e64554. [CrossRef]

164. Lafont, F.; Van Der Goot, F.G. Bacterial invasion via lipid rafts. Cell. Microbiol. 2005, 7, 613-620. [CrossRef]

165. Gagliardi, M.C.; Iwabuchi, K.; Lai, C.-H. Editorial: Role of Lipid Rafts in Anti-microbial Immune Response. Front. Immunol. 2021, 12. [CrossRef]

166. Duncan, M.J.; Shin, J.S.; Abraham, S.N. Microbial entry through caveolae: Variations on a theme. Cell. Microbiol. $2002,4,783-791$. [CrossRef]

167. Manes, S.; del Real, G.; Martinez, A.C. Pathogens: Raft hijackers. Nat. Rev. Immunol. 2003, 3, 557-568. [CrossRef]

168. Shin, J.S.; Abraham, S.N. Co-option of endocytic functions of cellular caveolae by pathogens. Immunology 2001, $102,2-7$. [CrossRef] [PubMed]

169. Duffney, P.F.; Embong, A.K.; McGuire, C.C.; Thatcher, T.H.; Phipps, R.P.; Sime, P.J. Cigarette smoke increases susceptibility to infection in lung epithelial cells by upregulating caveolin-dependent endocytosis. PLoS ONE 2020, 15, e0232102. [CrossRef] [PubMed]

170. Zaas, D.W.; Duncan, M.J.; Li, G.; Wright, J.R.; Abraham, S.N. Pseudomonas invasion of type I pneumocytes is dependent on the expression and phosphorylation of caveolin-2. J. Biol. Chem. 2005, 280, 4864-4872. [CrossRef] [PubMed]

171. Grassmé, H.; Jendrossek, V.; Riehle, A.; von Kürthy, G.; Berger, J.; Schwarz, H.; Weller, M.; Kolesnick, R.; Gulbins, E. Host defense against Pseudomonas aeruginosa requires ceramide-rich membrane rafts. Nat. Med. 2003, 9, 322-330. [CrossRef] [PubMed]

172. Garcia-Medina, R.; Dunne, W.M.; Singh, P.K.; Brody, S.L. Pseudomonas aeruginosa acquires biofilm-like properties within airway epithelial cells. Infect. Immun. 2005, 73, 8298-8305. [CrossRef] [PubMed] 
173. Grassme, H.; Becker, K.A. Bacterial infections and ceramide. Handb. Exp. Pharm. 2013, 305-320. [CrossRef]

174. Grassmé, H.; Schwarz, H.; Gulbins, E. Molecular mechanisms of ceramide-mediated CD95 clustering. Biochem. Biophys. Res. Commun. 2001, 284, 1016-1030. [CrossRef] [PubMed]

175. Avota, E.; de Lira, M.N.; Schneider-Schaulies, S. Sphingomyelin Breakdown in T Cells: Role of Membrane Compartmentalization in T Cell Signaling and Interference by a Pathogen. Front. Cell Dev. Biol. 2019, 7, 152. [CrossRef]

176. Seitz, A.P.; Grassmé, H.; Edwards, M.J.; Pewzner-Jung, Y.; Gulbins, E. Ceramide and sphingosine in pulmonary infections. Biol. Chem. 2015, 396, 611-620. [CrossRef]

177. Zhang, Y.; Li, X.; Carpinteiro, A.; Gulbins, E. Acid sphingomyelinase amplifies redox signaling in Pseudomonas aeruginosainduced macrophage apoptosis. J. Immunol. 2008, 181, 4247-4254. [CrossRef]

178. Kunz, T.C.; Kozjak-Pavlovic, V. Diverse Facets of Sphingolipid Involvement in Bacterial Infections. Front. Cell Dev. Biol. 2019, 7. [CrossRef]

179. Manago, A.; Becker, K.A.; Carpinteiro, A.; Wilker, B.; Soddemann, M.; Seitz, A.P.; Edwards, M.J.; Grassme, H.; Szabo, I.; Gulbins, E. Pseudomonas aeruginosa pyocyanin induces neutrophil death via mitochondrial reactive oxygen species and mitochondrial acid sphingomyelinase. Antioxid. Redox Signal. 2015, 22, 1097-1110. [CrossRef] [PubMed]

180. Ganesan, V.; Perera, M.N.; Colombini, D.; Datskovskiy, D.; Chadha, K.; Colombini, M. Ceramide and activated Bax act synergistically to permeabilize the mitochondrial outer membrane. Apoptosis 2010, 15, 553-562. [CrossRef]

181. Rolando, M.; Buchrieser, C. A Comprehensive Review on the Manipulation of the Sphingolipid Pathway by Pathogenic Bacteria. Front. Cell Dev. Biol. 2019, 7, 168. [CrossRef] [PubMed]

182. Huang, H.; Weaver, A.; Wu, E.; Li, Y.; Gao, H.; Fan, W.; Wu, M. Lipid-based signaling modulates DNA repair response and survival against Klebsiella pneumoniae infection in host cells and in mice. Am. J. Respir. Cell Mol. Biol. 2013, 49, $798-807$. [CrossRef]

183. Yuan, K.; Huang, C.; Fox, J.; Gaid, M.; Weaver, A.; Li, G.; Singh, B.B.; Gao, H.; Wu, M. Elevated inflammatory response in caveolin-1-deficient mice with Pseudomonas aeruginosa infection is mediated by STAT3 protein and nuclear factor kappaB (NF-kappaB). J. Biol. Chem. 2011, 286, 21814-21825. [CrossRef]

184. Bajmoczi, M.; Gadjeva, M.; Alper, S.L.; Pier, G.B.; Golan, D.E. Cystic fibrosis transmembrane conductance regulator and caveolin-1 regulate epithelial cell internalization of Pseudomonas aeruginosa. Am. J. Physiol. Cell Physiol. 2009, 297, C263-C277. [CrossRef] [PubMed]

185. Gadjeva, M.; Paradis-Bleau, C.; Priebe, G.P.; Fichorova, R.; Pier, G.B. Caveolin-1 modifies the immunity to Pseudomonas aeruginosa. J. Immunol. 2010, 184, 296-302. [CrossRef] [PubMed]

186. Lin, Y.-C.; Lin, C.-H.; Kuo, C.-Y.; Yang, V.C. ABCA1 modulates the oligomerization and Golgi exit of caveolin-1 during HDLmediated cholesterol efflux in aortic endothelial cells. Biochem. Biophys. Res. Commun. 2009, 382, 189-195. [CrossRef] [PubMed]

187. Agassandian, M.; Miakotina, O.L.; Andrews, M.; Mathur, S.N.; Mallampalli, R.K. Pseudomonas aeruginosa and sPLA2 IB stimulate ABCA1-mediated phospholipid efflux via ERK-activation of PPARalpha-RXR. Biochem. J. 2007, 403, 409-420. [CrossRef] [PubMed]

188. Ares, M.A.; Sansabas, A.; Rodriguez-Valverde, D.; Siqueiros-Cendon, T.; Rascon-Cruz, Q.; Rosales-Reyes, R.; Jarillo-Quijada, M.D.; Alcantar-Curiel, M.D.; Cedillo, M.L.; Torres, J.; et al. The Interaction of Klebsiella pneumoniae With Lipid Rafts-Associated Cholesterol Increases Macrophage-Mediated Phagocytosis Due to Down Regulation of the Capsule Polysaccharide. Front. Cell. Infect. Microbiol. 2019, 9, 255. [CrossRef]

189. Cano, V.; March, C.; Insua, J.L.; Aguiló, N.; Llobet, E.; Moranta, D.; Regueiro, V.; Brennan, G.P.; Millán-Lou, M.I.; Martín, C.; et al. Klebsiella pneumoniae survives within macrophages by avoiding delivery to lysosomes. Cell. Microbiol. 2015, 17, 1537-1560. [CrossRef] [PubMed]

190. Sharma, L.; Feng, J.; Britto, C.J.; Dela Cruz, C.S. Mechanisms of Epithelial Immunity Evasion by Respiratory Bacterial Pathogens. Front. Immunol. 2020, 11, 91. [CrossRef]

191. Sahly, H.; Podschun, R.; Oelschlaeger, T.A.; Greiwe, M.; Parolis, H.; Hasty, D.; Kekow, J.; Ullmann, U.; Ofek, I.; Sela, S. Capsule Impedes Adhesion to and Invasion of Epithelial Cells by Klebsiella pneumoniae. Infect. Immun. 2000, 68, 6744-6749. [CrossRef]

192. Cortés, G.; Alvarez, D.; Saus, C.; Albertí, S. Role of lung epithelial cells in defense against Klebsiella pneumoniae pneumonia. Infect. Immun. 2002, 70, 1075-1080. [CrossRef] [PubMed]

193. Bengoechea, J.A.; Sa Pessoa, J. Klebsiella pneumoniae infection biology: Living to counteract host defences. FEMS Microbiol. Rev. 2018, 43, 123-144. [CrossRef] [PubMed]

194. Bertuzzi, M.; Hayes, G.E.; Bignell, E.M. Microbial uptake by the respiratory epithelium: Outcomes for host and pathogen. FEMS Microbiol. Rev. 2019, 43, 145-161. [CrossRef]

195. Chang, D.; Feng, J.; Liu, H.; Liu, W.; Sharma, L.; Dela Cruz, C.S. Differential effects of the Akt pathway on the internalization of Klebsiella by lung epithelium and macrophages. Innate Immun. 2020, 26, 618-626. [CrossRef] [PubMed]

196. Struve, C.; Krogfelt, K.A. Role of capsule in Klebsiella pneumoniae virulence: Lack of correlation between in vitro and in vivo studies. FEMS Microbiol. Lett. 2003, 218, 149-154. [CrossRef] [PubMed]

197. Rendueles, O. Deciphering the role of the capsule of Klebsiella pneumoniae during pathogenesis: A cautionary tale. Mol. Microbiol. 2020, 113, 883-888. [CrossRef] 
198. Baker, L.Y.; Hobby, C.R.; Siv, A.W.; Bible, W.C.; Glennon, M.S.; Anderson, D.M.; Symes, S.J.; Giles, D.K. Pseudomonas aeruginosa responds to exogenous polyunsaturated fatty acids (PUFAs) by modifying phospholipid composition, membrane permeability, and phenotypes associated with virulence. BMC Microbiol. 2018, 18, 117. [CrossRef]

199. Torreggiani, A.; Tinti, A.; Jurasekova, Z.; Capdevila, M.; Saracino, M.; Foggia, M.D. Structural Lesions of Proteins Connected to Lipid Membrane Damages Caused by Radical Stress: Assessment by Biomimetic Systems and Raman Spectroscopy. Biomolecules 2019, 9, 794. [CrossRef]

200. Heipieper, H.J.; Meinhardt, F.; Segura, A. The cis-trans isomerase of unsaturated fatty acids in Pseudomonas and Vibrio: Biochemistry, molecular biology and physiological function of a unique stress adaptive mechanism. FEMS Microbiol. Lett. 2003, 229, 1-7. [CrossRef]

201. Hobby, C.R.; Herndon, J.L.; Morrow, C.A.; Peters, R.E.; Symes, S.J.K.; Giles, D.K. Exogenous fatty acids alter phospholipid composition, membrane permeability, capacity for biofilm formation, and antimicrobial peptide susceptibility in Klebsiella pneumoniae. MicrobiologyOpen 2019, 8, e00635. [CrossRef]

202. Bailie, M.B.; Standiford, T.J.; Laichalk, L.L.; Coffey, M.J.; Strieter, R.; Peters-Golden, M. Leukotriene-deficient mice manifest enhanced lethality from Klebsiella pneumonia in association with decreased alveolar macrophage phagocytic and bactericidal activities. J. Immunol. 1996, 157, 5221-5224.

203. Ricciotti, E.; FitzGerald, G.A. Prostaglandins and inflammation. Arterioscler. Thromb. Vasc. Biol. 2011, 31, 986-1000. [CrossRef] [PubMed]

204. Jurado-Martín, I.; Sainz-Mejías, M.; McClean, S. Pseudomonas aeruginosa: An Audacious Pathogen with an Adaptable Arsenal of Virulence Factors. Int. J. Mol. Sci. 2021, 22, 3128. [CrossRef] [PubMed]

205. Schaar, V.; de Vries, S.P.W.; Perez Vidakovics, M.L.A.; Bootsma, H.J.; Larsson, L.; Hermans, P.W.M.; Bjartell, A.; Mörgelin, M.; Riesbeck, K. Multicomponent Moraxella catarrhalis outer membrane vesicles induce an inflammatory response and are internalized by human epithelial cells. Cell. Microbiol. 2011, 13, 432-449. [CrossRef] [PubMed]

206. Bomberger, J.M.; Maceachran, D.P.; Coutermarsh, B.A.; Ye, S.; O’Toole, G.A.; Stanton, B.A. Long-distance delivery of bacterial virulence factors by Pseudomonas aeruginosa outer membrane vesicles. PLoS Pathog. 2009, 5, e1000382. [CrossRef]

207. Behrens, F.; Funk-Hilsdorf, T.C.; Kuebler, W.M.; Simmons, S. Bacterial Membrane Vesicles in Pneumonia: From Mediators of Virulence to Innovative Vaccine Candidates. Int. J. Mol. Sci. 2021, 22, 3858. [CrossRef] [PubMed]

208. Oda, M.; Hashimoto, M.; Takahashi, M.; Ohmae, Y.; Seike, S.; Kato, R.; Fujita, A.; Tsuge, H.; Nagahama, M.; Ochi, S.; et al. Role of sphingomyelinase in infectious diseases caused by Bacillus cereus. PLoS ONE 2012, 7, e38054. [CrossRef] [PubMed]

209. Zhang, Y.-M.; Rock, C.O. Membrane lipid homeostasis in bacteria. Nat. Rev. Microbiol. 2008, 6, 222-233. [CrossRef] [PubMed]

210. Aguilar, P.S.; De Mendoza, D. Control of fatty acid desaturation: A mechanism conserved from bacteria to humans. Mol. Microbiol. 2006, 62, 1507-1514. [CrossRef]

211. Fernández-Calvet, A.; Rodríguez-Arce, I.; Almagro, G.; Moleres, J.; Euba, B.; Caballero, L.; Martí, S.; Ramos-Vivas, J.; Bartholomew, T.L.; Morales, X.; et al. Modulation of Haemophilus influenzae interaction with hydrophobic molecules by the VacJ/MlaA lipoprotein impacts strongly on its interplay with the airways. Sci. Rep. 2018, 8, 6872. [CrossRef]

212. Gordon, S. Phagocytosis: An Immunobiologic Process. Immunity 2016, 44, 463-475. [CrossRef]

213. Underhill, D.M.; Goodridge, H.S. Information processing during phagocytosis. Nat. Rev. Immunol. 2012, 12, 492-502. [CrossRef]

214. Berenson, C.S.; Wrona, C.T.; Grove, L.J.; Maloney, J.; Garlipp, M.A.; Wallace, P.K.; Stewart, C.C.; Sethi, S. Impaired alveolar macrophage response to Haemophilus antigens in chronic obstructive lung disease. Am. J. Respir. Crit. Care Med. 2006, 174, 31-40. [CrossRef]

215. Henson, P.M. Cell Removal: Efferocytosis. Annu. Rev. Cell Dev. Biol. 2017, 33, 127-144. [CrossRef] [PubMed]

216. Birge, R.B.; Boeltz, S.; Kumar, S.; Carlson, J.; Wanderley, J.; Calianese, D.; Barcinski, M.; Brekken, R.A.; Huang, X.; Hutchins, J.T.; et al. Phosphatidylserine is a global immunosuppressive signal in efferocytosis, infectious disease, and cancer. Cell Death Differ. 2016, 23, 962-978. [CrossRef]

217. Barnes, P.J. Inflammatory mechanisms in patients with chronic obstructive pulmonary disease. J. Allergy Clin. Immunol. 2016, 138, 16-27. [CrossRef]

218. Russell, R.E.; Culpitt, S.V.; DeMatos, C.; Donnelly, L.; Smith, M.; Wiggins, J.; Barnes, P.J. Release and activity of matrix metalloproteinase- 9 and tissue inhibitor of metalloproteinase- 1 by alveolar macrophages from patients with chronic obstructive pulmonary disease. Am. J. Respir. Cell Mol. Biol. 2002, 26, 602-609. [CrossRef] [PubMed]

219. Barbers, R.G.; Evans, M.J.; Gong, H., Jr.; Tashkin, D.P. Enhanced alveolar monocytic phagocyte (macrophage) proliferation in tobacco and marijuana smokers. Am. Rev. Respir. Dis. 1991, 143, 1092-1095. [CrossRef] [PubMed]

220. Bitterman, P.B.; Saltzman, L.E.; Adelberg, S.; Ferrans, V.J.; Crystal, R.G. Alveolar macrophage replication. One mechanism for the expansion of the mononuclear phagocyte population in the chronically inflamed lung. J. Clin. Investig. 1984, 74, 460-469. [CrossRef]

221. Taylor, A.E.; Finney-Hayward, T.K.; Quint, J.K.; Thomas, C.M.; Tudhope, S.J.; Wedzicha, J.A.; Barnes, P.J.; Donnelly, L.E. Defective macrophage phagocytosis of bacteria in COPD. Eur. Respir. J. 2010, 35, 1039-1047. [CrossRef] [PubMed]

222. Berenson, C.S.; Kruzel, R.L.; Eberhardt, E.; Sethi, S. Phagocytic dysfunction of human alveolar macrophages and severity of chronic obstructive pulmonary disease. J. Infect. Dis. 2013, 208, 2036-2045. [CrossRef]

223. Berenson, C.S.; Garlipp, M.A.; Grove, L.J.; Maloney, J.; Sethi, S. Impaired Phagocytosis of Nontypeable Haemophilus influenzae by Human Alveolar Macrophages in Chronic Obstructive Pulmonary Disease. J. Infect. Dis. 2006, 194, 1375-1384. [CrossRef] 
224. Sethi, S.; Murphy, T.F. Bacterial infection in chronic obstructive pulmonary disease in 2000: A state-of-the-art review. Clin. Microbiol. Rev. 2001, 14, 336-363. [CrossRef] [PubMed]

225. Singh, R.; Belchamber, K.B.R.; Fenwick, P.S.; Chana, K.; Donaldson, G.; Wedzicha, J.A.; Barnes, P.J.; Donnelly, L.E.; COPDMAP consortium. Defective monocyte-derived macrophage phagocytosis is associated with exacerbation frequency in COPD. Respir. Res. 2021, 22, 113. [CrossRef] [PubMed]

226. Ghosh, B.; Gaike, A.H.; Pyasi, K.; Brashier, B.; Das, V.V.; Londhe, J.D.; Juvekar, S.; Shouche, Y.S.; Donnelly, L.E.; Salvi, S.S.; et al. Bacterial load and defective monocyte-derived macrophage bacterial phagocytosis in biomass smoke-related COPD. Eur. Respir. J. 2019, 53. [CrossRef] [PubMed]

227. Hodge, S.; Hodge, G.; Scicchitano, R.; Reynolds, P.N.; Holmes, M. Alveolar macrophages from subjects with chronic obstructive pulmonary disease are deficient in their ability to phagocytose apoptotic airway epithelial cells. Immunol. Cell Biol. 2003, 81, 289-296. [CrossRef] [PubMed]

228. Ween, M.; Ahern, J.; Carroll, A.; Hodge, G.; Pizzutto, S.; Jersmann, H.; Reynolds, P.; Hodge, S. A small volume technique to examine and compare alveolar macrophage phagocytosis of apoptotic cells and non typeable Haemophilus influenzae (NTHi). J. Immunol. Methods 2016, 429, 7-14. [CrossRef] [PubMed]

229. Vandivier, R.W.; Henson, P.M.; Douglas, I.S. Burying the dead: The impact of failed apoptotic cell removal (efferocytosis) on chronic inflammatory lung disease. Chest 2006, 129, 1673-1682. [CrossRef]

230. Thayaparan, D.; Shen, P.; Stämpfli, M.R.; Morissette, M.C. Induction of pulmonary antibodies against oxidized lipids in mice exposed to cigarette smoke. Respir. Res. 2016, 17, 97. [CrossRef]

231. Morissette, M.C.; Shen, P.; Thayaparan, D.; Stämpfli, M.R. Disruption of pulmonary lipid homeostasis drives cigarette smokeinduced lung inflammation in mice. Eur. Respir. J. 2015, 46, 1451-1460. [CrossRef]

232. Chen, W.; Li, L.; Wang, J.; Zhang, R.; Zhang, T.; Wu, Y.; Wang, S.; Xing, D. The ABCA1-efferocytosis axis: A new strategy to protect against atherosclerosis. Clin. Chim. Acta 2021, 518, 1-8. [CrossRef]

233. Elbach, P. Composition and synthesis of lipids in resting and phagocytizing leukocytes. J. Exp. Med. 1959, 110, 969-980. [CrossRef] [PubMed]

234. Elsbach, P.; Levy, S. Increased synthesis of phospholipid during phagocytosis. J. Clin. Investig. 1968, 47, 2217-2229. [CrossRef] [PubMed]

235. Smolen, J.E.; Shohet, S.B. Remodeling of granulocyte membrane fatty acids during phagocytosis. J. Clin. Investig. 1974, 53, 726-734. [CrossRef] [PubMed]

236. Fuhrmann, H.; Miles, E.A.; West, A.L.; Calder, P.C. Membrane fatty acids, oxidative burst and phagocytosis after enrichment of P388D1 monocyte/macrophages with essential 18-carbon fatty acids. Ann. Nutr. Metab. 2007, 51, 155-162. [CrossRef]

237. Schroit, A.J.; Gallily, R. Macrophage fatty acid composition and phagocytosis: Effect of unsaturation on cellular phagocytic activity. Immunology 1979, 36, 199-205. [PubMed]

238. Gonzalez-Ferrer, S.; Peñaloza, H.F.; Budnick, J.A.; Bain, W.G.; Nordstrom, H.R.; Lee, J.S.; Van Tyne, D. Finding Order in the Chaos: Outstanding Questions in Klebsiella pneumoniae Pathogenesis. Infect. Immun. 2021, 89, e00693-20. [CrossRef]

239. Jondle, C.N.; Gupta, K.; Mishra, B.B.; Sharma, J. Klebsiella pneumoniae infection of murine neutrophils impairs their efferocytic clearance by modulating cell death machinery. PLoS Pathog. 2018, 14, e1007338. [CrossRef]

240. Zheng, D.J.; Abou Taka, M.; Heit, B. Role of Apoptotic Cell Clearance in Pneumonia and Inflammatory Lung Disease. Pathogens 2021, 10, 134. [CrossRef]

241. Lemke, G. How macrophages deal with death. Nat. Rev. Immunol. 2019, 19, 539-549. [CrossRef]

242. Nagata, S. Apoptosis and Clearance of Apoptotic Cells. Annu. Rev. Immunol. 2018, 36, 489-517. [CrossRef]

243. Ahn, D.; Prince, A. Participation of Necroptosis in the Host Response to Acute Bacterial Pneumonia. J. Innate Immun. 2017, 9 , 262-270. [CrossRef]

244. Werz, O.; Gerstmeier, J.; Libreros, S.; De la Rosa, X.; Werner, M.; Norris, P.C.; Chiang, N.; Serhan, C.N. Human macrophages differentially produce specific resolvin or leukotriene signals that depend on bacterial pathogenicity. Nat. Commun. 2018, 9, 59. [CrossRef] [PubMed]

245. Haeggström, J.Z.; Funk, C.D. Lipoxygenase and leukotriene pathways: Biochemistry, biology, and roles in disease. Chem. Rev. 2011, 111, 5866-5898. [CrossRef] [PubMed]

246. Sandhaus, S.; Swick, A.G. Specialized proresolving mediators in infection and lung injury. Biofactors 2021, 47, 6-18. [CrossRef]

247. Buckley, C.D.; Gilroy, D.W.; Serhan, C.N. Proresolving lipid mediators and mechanisms in the resolution of acute inflammation. Immunity 2014, 40, 315-327. [CrossRef] [PubMed]

248. Chiang, N.; Fredman, G.; Bäckhed, F.; Oh, S.F.; Vickery, T.; Schmidt, B.A.; Serhan, C.N. Infection regulates pro-resolving mediators that lower antibiotic requirements. Nature 2012, 484, 524-528. [CrossRef]

249. Serhan, C.N.; Chiang, N.; Van Dyke, T.E. Resolving inflammation: Dual anti-inflammatory and pro-resolution lipid mediators. Nat. Rev. Immunol. 2008, 8, 349-361. [CrossRef] [PubMed]

250. Serhan, C.N. Pro-resolving lipid mediators are leads for resolution physiology. Nature 2014, 510, 92-101. [CrossRef] [PubMed]

251. Serhan, C.N.; Levy, B.D. Resolvins in inflammation: Emergence of the pro-resolving superfamily of mediators. J. Clin. Investig. 2018, 128, 2657-2669. [CrossRef] [PubMed]

252. Thatcher, T.H.; Woeller, C.F.; McCarthy, C.E.; Sime, P.J. Quenching the fires: Pro-resolving mediators, air pollution, and smoking. Pharm. Ther. 2019, 197, 212-224. [CrossRef] [PubMed] 
253. Levy, B.D.; Clish, C.B.; Schmidt, B.; Gronert, K.; Serhan, C.N. Lipid mediator class switching during acute inflammation: Signals in resolution. Nat. Immunol. 2001, 2, 612-619. [CrossRef] [PubMed]

254. Kantarci, A.; Van Dyke, T.E. Lipoxins in chronic inflammation. Crit. Rev. Oral Biol. Med. 2003, 14, 4-12. [CrossRef] [PubMed]

255. Chiang, N.; Serhan, C.N. Specialized pro-resolving mediator network: An update on production and actions. Essays Biochem. 2020, 64, 443-462. [CrossRef] [PubMed]

256. Calder, P.C. n-3 fatty acids, inflammation and immunity: New mechanisms to explain old actions. Proc. Nutr. Soc. 2013, 72, 326-336. [CrossRef] [PubMed]

257. Duvall, M.G.; Levy, B.D. DHA- and EPA-derived resolvins, protectins, and maresins in airway inflammation. Eur. J. Pharm. 2016, 785, 144-155. [CrossRef]

258. Kasuga, K.; Yang, R.; Porter, T.F.; Agrawal, N.; Petasis, N.A.; Irimia, D.; Toner, M.; Serhan, C.N. Rapid appearance of resolvin precursors in inflammatory exudates: Novel mechanisms in resolution. J. Immunol. 2008, 181, 8677-8687. [CrossRef]

259. Krishnamoorthy, N.; Abdulnour, R.-E.E.; Walker, K.H.; Engstrom, B.D.; Levy, B.D. Specialized Proresolving Mediators in Innate and Adaptive Immune Responses in Airway Diseases. Physiol. Rev. 2018, 98, 1335-1370. [CrossRef]

260. Balta, M.G.; Papathanasiou, E.; Christopoulos, P.F. Specialized Pro-Resolving Mediators as Potential Regulators of Inflammatory Macrophage Responses in COVID-19. Front. Immunol. 2021, 12. [CrossRef]

261. Decker, C.; Sadhu, S.; Fredman, G. Pro-Resolving Ligands Orchestrate Phagocytosis. Front. Immunol. 2021, 12, 660865. [CrossRef]

262. Basil, M.C.; Levy, B.D. Specialized pro-resolving mediators: Endogenous regulators of infection and inflammation. Nat. Rev. Immunol. 2016, 16, 51-67. [CrossRef] [PubMed]

263. Duvall, M.G.; Bruggemann, T.R.; Levy, B.D. Bronchoprotective mechanisms for specialized pro-resolving mediators in the resolution of lung inflammation. Mol. Asp. Med. 2017, 58, 44-56. [CrossRef] [PubMed]

264. De Batlle, J.; Sauleda, J.; Balcells, E.; Gómez, F.P.; Méndez, M.; Rodriguez, E.; Barreiro, E.; Ferrer, J.J.; Romieu, I.; Gea, J.; et al. Association between $\Omega 3$ and $\Omega 6$ fatty acid intakes and serum inflammatory markers in COPD. J. Nutr. Biochem. 2012, 23, 817-821. [CrossRef]

265. Drozdovszky, O.; Barta, I.; Antus, B. Sputum eicosanoid profiling in exacerbations of chronic obstructive pulmonary disease. Respiration 2014, 87, 408-415. [CrossRef]

266. Fritscher, L.G.; Post, M.; Rodrigues, M.T.; Silverman, F.; Balter, M.; Chapman, K.R.; Zamel, N. Profile of eicosanoids in breath condensate in asthma and COPD. J. Breath Res. 2012, 6, 026001. [CrossRef] [PubMed]

267. Bhat, T.A.; Kalathil, S.G.; Miller, A.; Thatcher, T.H.; Sime, P.J.; Thanavala, Y. Specialized Proresolving Mediators Overcome Immune Suppression Induced by Exposure to Secondhand Smoke. J. Immunol. 2020, 205, 3205-3217. [CrossRef] [PubMed]

268. Bozinovski, S.; Uddin, M.; Vlahos, R.; Thompson, M.; McQualter, J.L.; Merritt, A.S.; Wark, P.A.; Hutchinson, A.; Irving, L.B.; Levy, B.D.; et al. Serum amyloid A opposes lipoxin $\mathrm{A}_{4}$ to mediate glucocorticoid refractory lung inflammation in chronic obstructive pulmonary disease. Proc. Natl. Acad. Sci. USA 2012, 109, 935-940. [CrossRef] [PubMed]

269. Kim, K.-H.; Park, T.S.; Kim, Y.-S.; Lee, J.S.; Oh, Y.-M.; Lee, S.-D.; Lee, S.W. Resolvin D1 prevents smoking-induced emphysema and promotes lung tissue regeneration. Int. J. Chronic Obs. Pulm. Dis. 2016, 11, 1119-1128. [CrossRef]

270. Hsiao, H.-M.; Sapinoro, R.E.; Thatcher, T.H.; Croasdell, A.; Levy, E.P.; Fulton, R.A.; Olsen, K.C.; Pollock, S.J.; Serhan, C.N.; Phipps, R.P.; et al. A novel anti-inflammatory and pro-resolving role for resolvin D1 in acute cigarette smoke-induced lung inflammation. PLoS ONE 2013, 8, e58258. [CrossRef]

271. Croasdell, A.; Thatcher, T.H.; Kottmann, R.M.; Colas, R.A.; Dalli, J.; Serhan, C.N.; Sime, P.J.; Phipps, R.P. Resolvins attenuate inflammation and promote resolution in cigarette smoke-exposed human macrophages. Am. J. Physiol. Lung Cell. Mol. Physiol. 2015, 309, L888-L901. [CrossRef]

272. Codagnone, M.; Cianci, E.; Lamolinara, A.; Mari, V.C.; Nespoli, A.; Isopi, E.; Mattoscio, D.; Arita, M.; Bragonzi, A.; Iezzi, M.; et al. Resolvin D1 enhances the resolution of lung inflammation caused by long-term Pseudomonas aeruginosa infection. Mucosal Immunol. 2018, 11, 35-49. [CrossRef] [PubMed]

273. Balode, L.; Strazda, G.; Jurka, N.; Kopeika, U.; Kislina, A.; Bukovskis, M.; Beinare, M.; Gardjušina, V.; Taivāns, I. Lipoxygenasederived arachidonic acid metabolites in chronic obstructive pulmonary disease. Medicina (Kaunas) 2012, 48, 292-298. [CrossRef] [PubMed]

274. Vance, R.E.; Hong, S.; Gronert, K.; Serhan, C.N.; Mekalanos, J.J. The opportunistic pathogen Pseudomonas aeruginosa carries a secretable arachidonate 15-lipoxygenase. Proc. Natl. Acad. Sci. USA 2004, 101, 2135-2139. [CrossRef]

275. Kirschnek, S.; Gulbins, E. Phospholipase A2 functions in Pseudomonas aeruginosa-induced apoptosis. Infect. Immun. 2006, 74, 850-860. [CrossRef]

276. Starkey, M.; Hickman, J.H.; Ma, L.; Zhang, N.; De Long, S.; Hinz, A.; Palacios, S.; Manoil, C.; Kirisits, M.J.; Starner, T.D.; et al. Pseudomonas aeruginosa rugose small-colony variants have adaptations that likely promote persistence in the cystic fibrosis lung. J. Bacteriol. 2009, 191, 3492-3503. [CrossRef]

277. Deschamps, J.D.; Ogunsola, A.F.; Jameson, J.B., 2nd; Yasgar, A.; Flitter, B.A.; Freedman, C.J.; Melvin, J.A.; Nguyen, J.V.M.H.; Maloney, D.J.; Jadhav, A.; et al. Biochemical and Cellular Characterization and Inhibitor Discovery of Pseudomonas aeruginosa 15-Lipoxygenase. Biochemistry 2016, 55, 3329-3340. [CrossRef] [PubMed]

278. Azimzadeh, S.; Mirzaie, M.; Jafari, M.; Mehrani, H.; Shariati, P.; Khodabandeh, M. Signaling network of lipids as a comprehensive scaffold for omics data integration in sputum of COPD patients. Biochim. Biophys. Acta BBA Mol. Cell Biol. Lipids 2015, 1851, 1383-1393. [CrossRef] [PubMed] 
279. Miró, O.; Alonso, J.R.; Jarreta, D.; Casademont, J.; Urbano-Márquez, A.; Cardellach, F. Smoking disturbs mitochondrial respiratory chain function and enhances lipid peroxidation on human circulating lymphocytes. Carcinogenesis 1999, 20, 1331-1336. [CrossRef]

280. Chatterjee, R.; Chowdhury, A.R.; Mukherjee, D.; Chakravortty, D. Lipid larceny: Channelizing host lipids for establishing successful pathogenesis by bacteria. Virulence 2021, 12, 195-216. [CrossRef]

281. Paulowski, L.; Donoghue, A.; Nehls, C.; Groth, S.; Koistinen, M.; Hagge, S.O.; Böhling, A.; Winterhalter, M.; Gutsmann, T. The Beauty of Asymmetric Membranes: Reconstitution of the Outer Membrane of Gram-Negative Bacteria. Front. Cell Dev. Biol. 2020, 8, 586. [CrossRef] [PubMed]

282. Kunz, L.I.Z.; ten Hacken, N.H.T.; Lapperre, T.S.; Timens, W.; Kerstjens, H.A.M.; van Schadewijk, A.; Vonk, J.M.; Sont, J.K.; Snoeck-Stroband, J.B.; Postma, D.S.; et al. Airway inflammation in COPD after long-term withdrawal of inhaled corticosteroids. Eur. Respir. J. 2017, 49, 1600839. [CrossRef]

283. Tantucci, C.; Pini, L. Inhaled Corticosteroids in COPD: Trying to Make a Long Story Short. Int. J. Chronic Obs. Pulm. Dis. 2020, 15, 821-829. [CrossRef]

284. Lee, J.H.; Park, Y.H.; Kang, D.R.; Lee, S.J.; Lee, M.K.; Kim, S.H.; Yong, S.J.; Lee, W.Y. Risk of Pneumonia Associated with Inhaled Corticosteroid in Patients with Chronic Obstructive Pulmonary Disease: A Korean Population-Based Study. Int. J. Chronic Obs. Pulm. Dis. 2020, 15, 3397-3406. [CrossRef] [PubMed]

285. Suissa, S.; Patenaude, V.; Lapi, F.; Ernst, P. Inhaled corticosteroids in COPD and the risk of serious pneumonia. Thorax 2013, 68, 1029-1036. [CrossRef] [PubMed]

286. Aksoy, M.O.; Li, X.; Borenstein, M.; Yi, Y.; Kelsen, S.G. Effects of topical corticosteroids on inflammatory mediator-induced eicosanoid release by human airway epithelial cells. J. Allergy Clin. Immunol. 1999, 103, 1081-1091. [CrossRef]

287. Hirata, F.; Schiffmann, E.; Venkatasubramanian, K.; Salomon, D.; Axelrod, J. A phospholipase A2 inhibitory protein in rabbit neutrophils induced by glucocorticoids. Proc. Natl. Acad. Sci. USA 1980, 77, 2533-2536. [CrossRef] [PubMed]

288. Hermoso, M.A.; Cidlowski, J.A. Putting the brake on inflammatory responses: The role of glucocorticoids. IUBMB Life 2003, 55, 497-504. [CrossRef] [PubMed]

289. Ericson-Neilsen, W.; Kaye, A.D. Steroids: Pharmacology, complications, and practice delivery issues. Ochsner J. 2014, 14, $203-207$.

290. Williams, D.M. Clinical Pharmacology of Corticosteroids. Respir. Care 2018, 63, 655-670. [CrossRef]

291. Malcher-Lopes, R.; Franco, A.; Tasker, J.G. Glucocorticoids shift arachidonic acid metabolism toward endocannabinoid synthesis: A non-genomic anti-inflammatory switch. Eur. J. Pharmacol. 2008, 583, 322-339. [CrossRef]

292. Young, R.P.; Hopkins, R.J. Update on the potential role of statins in chronic obstructive pulmonary disease and its co-morbidities. Expert Rev. Respir. Med. 2013, 7, 533-544. [CrossRef]

293. Young, R.P.; Hopkins, R.; Eaton, T.E. Pharmacological actions of statins: Potential utility in COPD. Eur. Respir. Rev. 2009, 18, 222-232. [CrossRef]

294. Walsh, A.; Perrem, L.; Khashan, A.S.; Henry, M.T.; Ni Chroinin, M. Statins versus placebo for people with chronic obstructive pulmonary disease. Cochrane Database Syst. Rev. 2019, 7, CD011959. [CrossRef] [PubMed]

295. Rezk, N.A.; Elewa, A. Anti inflammatory effects of statin in COPD. Egypt. J. Chest Dis. Tuberc. 2013, 62, 65-69. [CrossRef]

296. Damkjaer, M.; Hakansson, K.; Kallemose, T.; Ulrik, C.S.; Godtfredsen, N. Statins in High-Risk Chronic Obstructive Pulmonary Disease Outpatients: No Impact on Time to First Exacerbation and All-Cause Mortality-The STATUETTE Cohort Study. Int. J. Chronic Obs. Pulm. Dis. 2021, 16, 579-589. [CrossRef] [PubMed]

297. Raymakers, A.J.N.; Sadatsafavi, M.; Sin, D.D.; De Vera, M.A.; Lynd, L.D. The Impact of Statin Drug Use on All-Cause Mortality in Patients With COPD: A Population-Based Cohort Study. Chest 2017, 152, 486-493. [CrossRef]

298. Lu, Y.; Chang, R.; Yao, J.; Xu, X.; Teng, Y.; Cheng, N. Effectiveness of long-term using statins in COPD—A network meta-analysis. Respir. Res. 2019, 20, 17. [CrossRef]

299. Lin, C.M.; Yang, T.M.; Yang, Y.H.; Tsai, Y.H.; Lee, C.P.; Chen, P.C.; Chen, W.C.; Hsieh, M.J. Statin Use and the Risk of Subsequent Hospitalized Exacerbations in COPD Patients with Frequent Exacerbations. Int. J. Chronic Obs. Pulm. Dis. 2020, 15, 289-299. [CrossRef]

300. Cao, C.; Wu, Y.; Xu, Z.; Lv, D.; Zhang, C.; Lai, T.; Li, W.; Shen, H. The effect of statins on chronic obstructive pulmonary disease exacerbation and mortality: A systematic review and meta-analysis of observational research. Sci. Rep. 2015, 5, 16461. [CrossRef]

301. Ingebrigtsen, T.S.; Marott, J.L.; Nordestgaard, B.G.; Lange, P.; Hallas, J.; Vestbo, J. Statin use and exacerbations in individuals with chronic obstructive pulmonary disease. Thorax 2015, 70, 33-40. [CrossRef] [PubMed]

302. Huang, Y.J.; Kao, S.; Kao, L.T.; Chian, C.F.; Chung, C.H.; Chien, W.C.; Wang, K.Y. Association Between Statin Use and Exacerbation of Chronic Obstructive Pulmonary Disease Among Patients Receiving Corticosteroids. IInt. J. Chronic Obs. Pulm. Dis. 2021, 16, 591-602. [CrossRef]

303. Jin, Y.; Tachibana, I.; Takeda, Y.; He, P.; Kang, S.; Suzuki, M.; Kuhara, H.; Tetsumoto, S.; Tsujino, K.; Minami, T.; et al. Statins decrease lung inflammation in mice by upregulating tetraspanin CD9 in macrophages. PLoS ONE 2013, 8, e73706. [CrossRef]

304. Ko, H.H.T.; Lareu, R.R.; Dix, B.R.; Hughes, J.D. In vitro antibacterial effects of statins against bacterial pathogens causing skin infections. Eur. J. Clin. Microbiol. Infect. Dis. 2018, 37, 1125-1135. [CrossRef] [PubMed]

305. Fu, H.; Alabdullah, M.; Großmann, J.; Spieler, F.; Abdosh, R.; Lutz, V.; Kalies, K.; Knöpp, K.; Rieckmann, M.; Koch, S.; et al. The differential statin effect on cytokine production of monocytes or macrophages is mediated by differential geranylgeranylationdependent Rac1 activation. Cell Death Dis. 2019, 10, 880. [CrossRef] 
306. Masadeh, M.; Mhaidat, N.; Alzoubi, K.; Al-Azzam, S.; Alnasser, Z. Antibacterial activity of statins: A comparative study of atorvastatin, simvastatin, and rosuvastatin. Ann. Clin. Microbiol. Antimicrob. 2012, 11, 13. [CrossRef]

307. Hennessy, E.; O'Callaghan, J.; Mooij, M.J.; Legendre, C.; Camacho-Vanegas, O.; Camacho, S.C.; Adams, C.; Martignetti, J.A.; O'Gara, F. The impact of simvastatin on pulmonary effectors of Pseudomonas aeruginosa infection. PLoS ONE 2014, 9, e102200. [CrossRef]

308. Feng, L.; Zhou, L.; Sun, Y.; Gui, J.; Wang, X.; Wu, P.; Wan, J.; Ren, Y.; Qiu, S.; Wei, X.; et al. Specific inhibitions of annonaceous acetogenins on class II 3-hydroxy-3-methylglutaryl coenzyme A reductase from Streptococcus pneumoniae. Bioorg. Med. Chem. 2011, 19, 3512-3519. [CrossRef]

309. Galiullina, L.F.; Scheidt, H.A.; Huster, D.; Aganov, A.; Klochkov, V. Interaction of statins with phospholipid bilayers studied by solid-state NMR spectroscopy. Biochim. Biophys. Acta BBA Biomembr. 2019, 1861, 584-593. [CrossRef] [PubMed]

310. Zaborowska, M.; Broniatowski, M.; Wydro, P.; Matyszewska, D.; Bilewicz, R. Structural modifications of lipid membranes exposed to statins-Langmuir monolayer and PM-IRRAS study. J. Mol. Liq. 2020, 313, 113570. [CrossRef] 